\title{
Novel Therapeutic Strategies for Reducing Right Heart Failure Associated Mortality in Fibrotic Lung Diseases
}

\author{
Ayodeji Adegunsoye, ${ }^{1}$ Matthew Levy, ${ }^{2}$ and Olusegun Oyenuga ${ }^{3}$ \\ ${ }^{1}$ Section of Pulmonary \& Critical Care Medicine, Department of Medicine, University of Chicago, Chicago, IL 60637, USA \\ ${ }^{2}$ Department of Cardiology, Deborah Heart and Lung Center, Browns Mills, NJ 08015, USA \\ ${ }^{3}$ Section of Cardiology, Department of Medicine, University of Chicago, Chicago, IL 60637, USA \\ Correspondence should be addressed to Ayodeji Adegunsoye; drdayjee@yahoo.com
}

Received 28 March 2015; Accepted 26 August 2015

Academic Editor: Massimo F. Piepoli

Copyright (C) 2015 Ayodeji Adegunsoye et al. This is an open access article distributed under the Creative Commons Attribution License, which permits unrestricted use, distribution, and reproduction in any medium, provided the original work is properly cited.

\begin{abstract}
Fibrotic lung diseases carry a significant mortality burden worldwide. A large proportion of these deaths are due to right heart failure and pulmonary hypertension. Underlying contributory factors which appear to play a role in the mechanism of progression of right heart dysfunction include chronic hypoxia, defective calcium handling, hyperaldosteronism, pulmonary vascular alterations, cyclic strain of pressure and volume changes, elevation of circulating TGF- $\beta$, and elevated systemic NO levels. Specific therapies targeting pulmonary hypertension include calcium channel blockers, endothelin (ET-1) receptor antagonists, prostacyclin analogs, phosphodiesterase type 5 (PDE5) inhibitors, and rho-kinase (ROCK) inhibitors. Newer antifibrotic and anti-inflammatory agents may exert beneficial effects on heart failure in idiopathic pulmonary fibrosis. Furthermore, right ventricle-targeted therapies, aimed at mitigating the effects of functional right ventricular failure, include $\beta$-adrenoceptor ( $\beta$-AR) blockers, angiotensinconverting enzyme (ACE) inhibitors, antioxidants, modulators of metabolism, and 5-hydroxytryptamine-2B (5-HT2B) receptor antagonists. Newer nonpharmacologic modalities for right ventricular support are increasingly being implemented. Early, effective, and individualized therapy may prevent overt right heart failure in fibrotic lung disease leading to improved outcomes and quality of life.
\end{abstract}

\section{Introduction}

The interstitial lung diseases (ILD) comprise a heterogeneous group of pulmonary disorders with similar clinical and radiographic characteristics. Etiologies range from identifiable environmental and medication exposures to connective tissue diseases. A significant portion of ILD remains idiopathic amongst which the progressive fibrotic lung diseases are the most clinically challenging and carry significant mortality burden [1]. This category includes idiopathic pulmonary fibrosis (IPF), fibrotic nonspecific interstitial pneumonia (FNSIP), chronic hypersensitivity pneumonitis (CHP), and connective tissue disease related ILD (CTD-ILD).

Treatment of ILD is usually targeted at avoiding potential etiologic factors, correction of hypoxemia, and blunting the inflammatory response that ultimately results in fibrosis. Despite advances in medicine, the incidence and mortality of IPF, one of the more common fibrotic lung diseases, continue to rise worldwide. Cardiovascular comorbidities like right heart failure (RHF) and pulmonary hypertension $(\mathrm{PH})$ account for a large proportion of these deaths [2] and an effective approach to the management of these comorbid conditions constitutes an appealing target for improving outcomes and quality of life in this group of patients.

\section{Pulmonary Hypertension and Right Ventricular Dysfunction in Fibrotic Lung Diseases}

The development of PH in IPF patients has been associated with several mechanistic factors such as poor resting gas exchange, low diffusing capacity of the lungs for carbon monoxide (DLCO), increased desaturation with exercise, and 
cardiovascular mediated exercise limitation [3-5]. Although the gold standard for the diagnosis of $\mathrm{PH}$ is right heart catheterization, $\mathrm{PH}$ can also be assessed with noninvasive modalities with prognostic implications.

More than $60 \%$ of patients with end-stage IPF demonstrate mean pulmonary artery pressure (mPAP) $>25 \mathrm{mmHg}$ [5-7]. Though the mPAP exceeds $40 \mathrm{mmHg}$ in a fraction of these patients ( 9\%) [8], the extent of lung function impairment has not been shown to correlate significantly with severity of $\mathrm{PH}$ [8]. $\mathrm{PH}$ may rapidly progress in the later stages of IPF and other fibrotic lung diseases $[4,6]$. The prognostic implications of $\mathrm{PH}$ in fibrotic lung disease have been demonstrated with mPAP, pulmonary vascular resistance (PVR), and cardiac index (CI). CI below $2.4 \mathrm{~L} / \mathrm{min} / \mathrm{m}^{2}$ has been correlated with a limited life expectancy of several months [9-11]. Radiographic demonstration of right heart dilation and elevated serum levels of brain natriuretic peptide (BNP) also have prognostic significance with worsening $\mathrm{PH}$ in these patients [3-5]. Transthoracic echocardiogram (TTE) therefore remains a useful tool in the evaluation of $\mathrm{PH}$ and is currently the recommended method for early detection $[12,13]$. Systolic PAP measurements by TTE are sensitive (79-100\%) and specific (60-98\%) for detection of $\mathrm{PH}$ especially in the presence of tricuspid regurgitation [14, 15]. Patients with chronic fibrotic lung disease may however experience wide variations in TTE estimations of sPAP necessitating the implementation of more accurate modalities in identification of patients at risk $[16,17]$. The current guidelines for echocardiographic assessment of the right heart in adults also recommend the use of tricuspid annular plane systolic excursion (TAPSE) (reference range 1.5$2.0 \mathrm{~cm}$ ) also referred to as tricuspid annular motion (TAM), a simple and easily reproducible technique which provides measurements of right ventricular annular systolic excursion in a longitudinal plane when evaluated in a standard apical 4-chamber view [18]. Stress echocardiography and newer techniques such as right ventricular function parameters as measured by tissue Doppler (e.g., RV E/Em index) or right ventricular isovolumic relaxation time (RV-IVRT) may yield better indices and improved correlation with survival [10, $19,20]$. The combination of more than one measure of right ventricular function may provide more reliable indices to detect abnormal function [18].

Cardiac MR is an increasingly attractive modality for assessing the pulmonary artery and right ventricle in patients with pulmonary fibrosis [21, 22]. Contrast-enhanced CT scans can also be used to assess right ventricular size; interventricular septal deviation and demonstration of contrast reflux into the inferior vena cava in individuals with $\mathrm{PH}$ are specific for the presence of tricuspid regurgitation [23].

\section{Etiologic Factors in the Mechanism of Onset and Progression of Right Ventricular Dysfunction}

Right ventricular failure commonly complicates chronic $\mathrm{PH}$ and is the strongest prognostic factor in this group of patients
[24]. Right ventricular failure typically follows RV-PA uncoupling, which occurs when the elevated pulmonary vascular resistance exceeds the intrinsic contractility of the right ventricle. Unlike pulmonary arterial hypertension (PAH) in which disease severity of the distal pulmonary vasculature is thought to play key roles in occurrence of right ventricular hypertrophy and failure, the underlying mechanisms of right ventricular dysfunction in fibrotic lung diseases are not fully understood [25].

Experimental animal models of chronic $\mathrm{PH}$ have demonstrated the presence of diastolic dysfunction as an early marker for right ventricular remodeling and increased right ventricular fibrosis even in the absence of heart failure. Defective calcium handling, hyperaldosteronism, and RVPA uncoupling herald the onset of overt right ventricular failure [26] (Figure 1). Other studies demonstrate that absence of caveolin-1, a structural protein predominantly expressed in fibroblast and endothelial cells, results in marked secondary right ventricular hypertrophy following significant pulmonary hypertension, with elevation of systemic NO levels [27]. This elevation in systemic NO levels which characterizes cardiomyopathy and $\mathrm{PH}$ in human and animal models may reduce myocardial contractility and mediate the deleterious effects of various cytokines on intrinsic myocardial inotropic activity [28, 29] (Figure 1).

Significantly elevated circulating levels of TGF- $\beta$, a profibrotic mediator that promotes aberrant gene expression and abnormal collagen deposition such as that occurring in pulmonary fibrosis, have been demonstrated in patients with dilated cardiomyopathy and worsening congestive heart failure [30]. TGF- $\beta$ and IL-10 were also associated with increased pulmonary microvascular pressure and are thought to play key roles in cardiac and pulmonary fibrotic remodeling [30, 31]. TGF- $\beta$ produced by cardiomyoblasts have been demonstrated to induce airway squamous metaplasia through Smad signaling, a mechanism that could worsen airflow obstruction in individuals with heart failure [32].

Chronic hypoxia appears to modify the response of the right ventricular to pressure overload by the uncoupling of endothelial nitric oxide synthase thereby resulting in an accelerated decline in right ventricular function [33] (Figure 1). Cyclic strain of pressure and volume changes on the right heart result in increased right ventricular wall tension promoting development of myocardial hypertrophy [34-36]. The increased stretch of the ventricular wall upregulates the transcription of the BNP gene thereby increasing cardiomyocyte secretion of BNP [37]. Its inactive metabolite NT-pro-BNP correlates with measures of right ventricular dysfunction as determined by CMR or echocardiography and elevated baseline values $\left(>1,685 \mathrm{pg} \cdot \mathrm{mL}^{-1}\right)$ predict poor prognosis [38-40].

Multiorgan fibrotic infiltration has also been described to result in right ventricular dysfunction. Alstrom syndrome, an autosomal recessive condition characterized by blindness, dilated cardiomyopathy, and metabolic abnormalities, is associated with fibrotic lung disease, glomerulofibrosis, and sensorineural hearing loss [41]. Myocardial evaluation of these patients with cardiac magnetic resonance imaging 


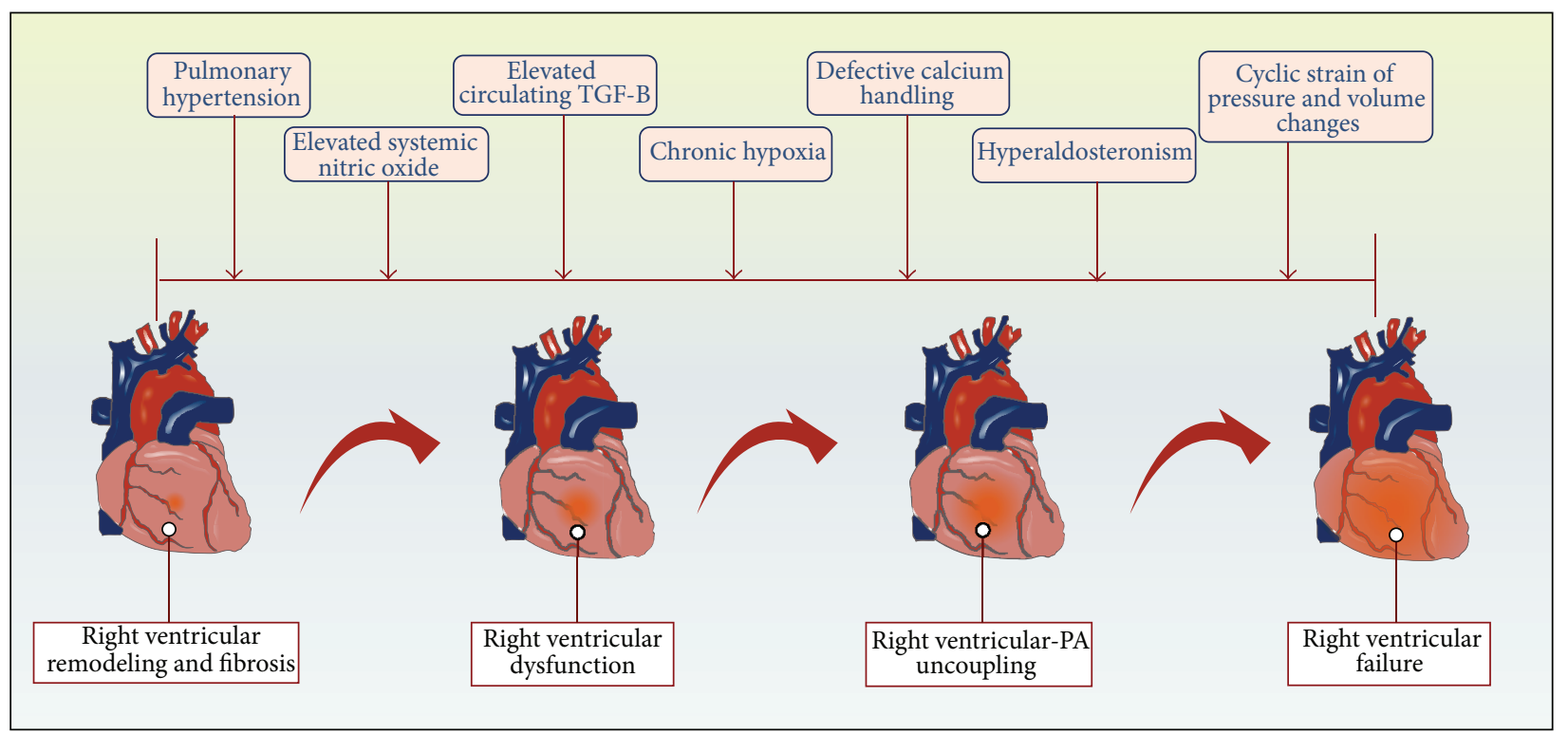

FIGURE 1: Factors associated with progression to right ventricular failure in fibrotic lung disease.

displays an absence of fluid or fatty infiltration. Instead all patients demonstrate a patchy distribution of myocardial fibrosis involving the left and right ventricles and concomitant impairment of biventricular function $[41,42]$.

\section{Mortality from Right Heart Failure in Fibrotic Lung Disease}

The interdependent physiologic mechanisms linking right heart failure to fibrotic lung disease reflect the anatomic proximity of these organs and the overall contribution to morbidity and mortality in patients with both conditions. As the worldwide aging population increased over the last few decades, hospitalizations for cardiovascular disease have also risen, a significant proportion of these due to heart failure [43-45]. The worldwide increase in the prevalence of heart failure and the 5-year mortality carried by this diagnosis exerts considerable socioeconomic impact on the affected individuals and the overall health care system [46]. Similarly, the occurrence of fibrotic lung disease may severely limit the life expectancy of affected patients such as the case in individuals with idiopathic pulmonary fibrosis where the median survival is 2-3 years rivaling that of several cancers [47]. A significant fraction of deaths in this subset of patients has been attributed to heart failure [48].

The contribution of right heart failure to mortality in fibrotic lung diseases involves a broad interplay of several pathophysiologic mechanisms such as structural alteration in the pulmonary vasculature with hemodynamic consequences, disequilibrium of pulmonary fluid homeostasis, occurrence of sleep disordered breathing, and distortion of pulmonary mechanics as evident on lung function testing.

4.1. Pulmonary Vascular Alterations. Despite high pulmonary pressures, which characterize right heart failure in fibrotic lung disease, these patients are less prone to developing pulmonary edema. Studies from autopsy findings and biopsy specimens suggest that the capillary bed undergoes several alterations including increased capillary dilation and thickness of the basement membrane, thickening of the tunica intima, and muscularization and circumferential fibrosis of the pulmonary vessels. These changes are accompanied by increased alveolar wall thickening following excessive collagen deposition, adjacent airway compression, and bronchial smooth muscle hypertrophy, processes amplified in the presence of underlying fibrotic lung disease [4951]. These vascular alterations appear to decrease capillary filtration rate and increase the level at which hydrostatic pressure produces pulmonary edema $[49,51]$.

4.2. Impairment of Pulmonary Fluid Homeostasis and Acute Pulmonary Edema. Progressive left heart failure increases left atrial pressure transmitted via pulmonary veins and capillaries to the right heart manifesting as pulmonary hypertension and ultimately right heart failure. Long standing pulmonary hypertension increases tolerance of high pressures with a lower tendency to develop pulmonary edema. However a rapid rise in the capillary wedge pressure may result in pulmonary edema even at low pressures. Elevated hydrostatic forces may partially disrupt the alveolar-capillary unit resulting in pulmonary capillary stress fracture and eventual pulmonary edema $[49,52,53]$.

4.3. Sleep Disordered Breathing. The presence of sleep disordered breathing commonly complicates heart failure and the associated sympathetic overactivity results in functional impairment and increased mortality $[54,55]$. Up to a third of patients with advanced heart failure exhibit central sleep apnea with increased morbidity and mortality [56, 57]. Also, 
the presence of obstructive sleep apnea is an independent risk factor for developing pulmonary hypertension and eventual cor pulmonale [36]. The importance of recognition of sleeprelated breathing disorders in idiopathic pulmonary fibrosis has resulted in its categorization by the International Classification of Sleep Disorders (ICSD) to a unique group, "sleep disorders with sleep-related hypoventilation and hypoxemia in parenchymal or vascular lung diseases" [58] most recently reclassified in 2014 to the specific subgroup, "sleep-related hypoxemia disorder" [59]. This is a result of the peculiar pattern of oxygen desaturation that characterizes this group of patients. These individuals exhibit multiple phasic oxygen desaturations which occur frequently from hypoventilation and may eventually lead to sleep fragmentation and poor quality of sleep [60].

\subsection{Impact of Heart Failure on Pulmonary Function Testing.} Studies examining the altered lung function in patients with decompensated heart failure are few. Patients acutely hospitalized for heart failure appear to have increased pulmonary resistance and demonstrate reduction in lung compliance, total lung capacity, FEV1, and FVC with no change in DLCO when compared to subsequent follow-up testing [61]. FEV1 and FVC have been demonstrated to be independent predictors of mortality in this cohort $[62,63]$. The restrictive physiology of pulmonary fibrosis may exacerbate these observed changes in the presence of concomitant heart failure. The contribution of heart failure to restrictive lung disease may be explained by the increased heart size in a fixed thoracic cavity thus reducing the functional lung volumes [64].

\section{Heart Failure Exacerbating Fibrotic Interstitial Lung Diseases}

Patients with fibrotic interstitial lung diseases often undergo acute respiratory decline, which may be due to the presence of congestive heart failure, venous thromboembolic disease, or infectious etiologies [65]. When careful exclusion of these causes has been performed, the acute respiratory deterioration is attributed to unexplained causes and is then termed acute exacerbation of interstitial lung disease (AE-ILD) such as acute exacerbations of idiopathic pulmonary fibrosis (AEIPF) [66-71]. Because heart failure commonly complicates the clinical course of fibrotic lung disease, patients who present with rapidly worsening pulmonary symptoms, oxygen desaturation, and acute onset of radiographic infiltrates in the past month should undergo thorough detailed clinical and transthoracic echocardiographic assessment of ventricular function with exclusion of pulmonary hypertension and venous thromboembolic disease as part of their diagnostic workup $[65,72]$. The therapeutic approach to management in these cases should target identifiable cardiac causes of respiratory decline in patients with fibrotic lung disease.

\section{Treatment of Pulmonary Hypertension Associated with Right Ventricular Dysfunction}

The sustained pulmonary vasoconstriction and progressive vascular remodeling that characterizes $\mathrm{PH}$ result in irreversible right heart dysfunction and ultimately acute decompensated right heart failure associated with high inhospital mortality [73-75]. The coexistence of chronic pulmonary disease and dysregulation of cellular proliferation may accelerate the World Health Organization (WHO) Functional Class (FC) decline of these patients into WHO-FC III or IV thus worsening survival outcomes [76-79].

The approach to treatment for these patients includes the use of oxygen and diuretics, as necessary, and anticoagulants in those individuals where specifically indicated $[80,81]$. It should however be noted that the use of pulmonary vasodilators in lung fibrosis may contribute to worsening of gas exchange by inhibiting hypoxic pulmonary vasoconstriction [82].

6.1. Idiopathic Pulmonary Fibrosis and Pulmonary Hypertension. Multiple studies evaluating the utility of pulmonary vasoactive agents in patients with IPF and other fibrotic lung diseases have failed to demonstrate significant mortality benefits and in certain instances demonstrated harmful effects Table 2. This may be due to the absence of demonstrable vasoreactivity in PH-IPF patients thus limiting the utility of pulmonary vasodilators such as calcium channel blockers. Other limitations of these studies included a focus on shortterm parameters, retrospective study design, and lack of randomization or inclusion of a placebo arm.

BUILD- (Bosentan Use in Interstitial Lung Disease-) 1 and BUILD-3 trials, which evaluated the effect of bosentan, a dual endothelin-1 receptor antagonist, in IPF failed to demonstrate a significant decrease in the time to IPF worsening [83, 84]. Macitentan, a novel dual endothelin receptor antagonist approved by the US FDA for treatment of $\mathrm{PAH}$, was evaluated for the treatment of IPF in the MUSIC (Macitentan Use in an Idiopathic Pulmonary Fibrosis Clinical Study) trial [85]. Though this medication was well tolerated, the study revealed no significant difference in survival, lung function, or time to disease worsening.

In the ARTEMIS-IPF (Randomized, Placebo-Controlled Study to Evaluate Safety and Effectiveness of Ambrisentan in IPF) trial, subgroup analysis of patients treated with ambrisentan based on their $\mathrm{PH}$ status demonstrated no significant effect in those with $\mathrm{mPAP}>25 \mathrm{mmHg}$; rather they seemed to have disease progression and increased hospitalization for respiratory causes [86]. The more recent BPHIT (Bosentan in Pulmonary Hypertension Associated with Fibrotic Idiopathic Interstitial Pneumonia) trial which evaluated the safety and clinical efficacy of bosentan in patients with $\mathrm{PH}$ and fibrotic idiopathic interstitial pneumonia revealed no demonstrable difference in symptoms, functional capacity, or pulmonary hemodynamics over a 16week period [87]. A subgroup analysis of patients enrolled in the STEP-IPF (Sildenafil Trial of Exercise Performance in 
Idiopathic Pulmonary Fibrosis) evaluated those patients with right ventricular systolic dysfunction but not right ventricular hypertrophy and found that those who received sildenafil demonstrated some improvement in 6-minute-walk distance but no difference in mortality or rate of acute exacerbations [88]. Further, a small pilot trial examining the effect of Riociguat on pulmonary hemodynamics in patients with $\mathrm{PH}$ and ILD of any cause demonstrated an acceptable safety profile [89].

Subsequently, the 2015 ATS/ERS/JRS/ALAT clinical practice guidelines strongly recommend that ambrisentan should not be used in patients with IPF regardless of the presence or absence of $\mathrm{PH}$ [90]. Also given the lack of mortality benefits and likelihood of net harm with the use of sildenafil, current recommendations are that sildenafil should not be used for treatment of IPF. The variability in reported outcomes across trials, increased cost, and imprecise estimates of their effect led to a recommendation against the use of bosentan or macitentan for the treatment of IPF. However, the guidelines note that these medications may benefit patients with PH-IPF more than other IPF patients.

While the previous 2011 ATS/ERS/JRS/ALAT clinical practice guidelines argued against treatment of $\mathrm{PH}$ in patients with IPF, the most recent update in 2015 makes no specific recommendation regarding this cohort and notes the lack of sufficient evidence to guide the clinical decision making process [90, 91]. Well-designed clinical trials of novel $\mathrm{PH}$ agents with acceptable safety profiles would help to determine the differential effect of treating $\mathrm{PH}$ in patients with IPF.

\subsection{Pulmonary Hypertension and Other Fibrotic Lung Dis-} eases. Fibrotic lung disease often results in $\mathrm{PH}$ (WHO Group 3 ), which may rapidly progress in the advanced stages [82]. However, some studies have shown that a reduction in cardiac index $<2.4 \mathrm{~L} / \mathrm{min} / \mathrm{m}^{2}$ rather than $\mathrm{mPAP}$ predicts poor survival, thus indicating that coexisting ventricular dysfunction may be of prognostic significance [82]. The current guidelines recommend that, in addition to long-term oxygen therapy to keep arterial oxygen saturation above $90 \%$, treatment of these patients should be focused on the underlying lung disease rather than the vascular component [82]. While it has been suggested that inhaled vasodilators may preferentially access those areas of the lungs with better ventilation and thereby improve oxygenation, supporting evidence in the form of large well-designed clinical trials is lacking.

Some patients with fibrotic lung disease may coincidentally develop PAH (WHO Group 1) as opposed to $\mathrm{PH}$ resulting from fibrotic lung disease (WHO Group 3) leading to uncertainty in patient classification $[82,92]$. Occasionally patients with systemic sclerosis who develop pulmonary fibrosis and $\mathrm{PH}$ may demonstrate similar pulmonary hemodynamics to idiopathic PAH, thus making their classification of $\mathrm{PH}$ challenging. Such cases should prompt a referral to centers of expertise for appropriate management [82].

The benefit of PAH therapy in non-IPF fibrotic lung diseases remains unclear and is presently limited to retrospective studies [93]. Riociguat, a soluble guanylate cyclase stimulator, has demonstrated some efficacy in initial trials of patients with PAH (Group 1), PH associated with FLD (Group 3), or chronic thromboembolic pulmonary hypertension (Group 4) [89, 94-97]. However, larger well-designed clinical trials are needed before adaptation for widespread use [90].

\subsection{Therapies for Pulmonary Arterial Hypertension}

6.3.1. Calcium Channel Blockers. The dihydropyridine calcium channel blockers such as nifedipine and amlodipine appear to be safe and well tolerated in patients with a positive pulmonary vasoreactive test and may confer a survival benefit in these individuals. However they may exert potentially negative inotropic effects with long-term consequences that remain unclear [98].

6.3.2. Endothelin (ET-1) Receptor Antagonists (ERA). Endothelin-1, a potent vasoconstrictor produced by vascular endothelial cells and cardiomyocytes, also mediates the regulation of several biological processes in other tissues outside the cardiovascular system [99-102]. The effects of ET-1 are mediated via two different receptor subtypes, $\mathrm{ET}_{\mathrm{A}}$ and $\mathrm{ET}_{\mathrm{B}}$. Endothelin (ET-1) receptor antagonists directly oppose its effects on cardiomyocyte contractility and the indirect effects on pulmonary vascular remodeling and vasoconstriction [103]. Bosentan, a nonselective receptor antagonist, was the first ERA to receive FDA approval for $\mathrm{PAH}$ in patients with WHO-FC III or IV. It has however been associated with sporadic increases in aminotransferases and anemia [104107]. Ambrisentan, an $\mathrm{ET}_{\mathrm{A}}$ selective antagonist, also improves exercise capacity with the added benefit of once daily dosing and a reduced tendency to cause aminotransferase abnormalities [108, 109]. Macitentan, the most recent oral ERA approved for use in these patients, was demonstrated to have a $45 \%$ reduction in morbidity and mortality and potential for use in patients with inoperable chronic thromboembolic pulmonary hypertension [110].

6.3.3. Prostacyclin Analogs. Prostacyclin (also called prostaglandin $\mathrm{I}_{2}$ or PGI2), a molecule that mediates vasodilation, inhibits platelet aggregation and inflammation and vascular smooth muscle proliferation also has important direct cardiac effects [111, 112]. Synthetic PGI2 analogs such as epoprostenol (Flolan) improve right ventricular stroke work and have demonstrated survival, functional, and hemodynamic benefits in patients with $\mathrm{PAH}$ [113-116]. The significantly short half-life (3-5 $\mathrm{min})$ and instability at room temperature presented practical challenges and more stable and convenient formulations (Veletri) have recently been made available with similar effects on pulmonary hemodynamics. Other PGI2 analogs such as treprostinil (which may be administered subcutaneously or intravenously or inhaled) and Iloprost (inhaled) may be used as alternative therapies [117-121]. Their direct effects on right ventricular function remain unclear and the initial improvement in exercise capacity observed with oral PGI2 analogs after 12 weeks has been reported to disappear after 1 year [122]. Furthermore, treatment with epoprostenol for 6 months has been reported to be associated with increased mortality, an effect that may be explained 
by the detrimental consequences of increasing myocardial oxygen consumption when contractility increases $[112,123$, 124].

6.3.4. Phosphodiesterase Type 5 (PDE5) Inhibitors. The formation of the intracellular messenger, cyclic guanosine monophosphate (cGMP), a potent smooth muscle relaxant and pulmonary vasodilator, is induced through activation of soluble guanylate cyclase (sGC) by nitric oxide (NO), a short-acting molecule produced by vascular endothelial cells [125]. The phosphodiesterase type 5 (PDE5) enzyme degrades cGMP; thus oral PDE5 inhibitors such as sildenafil and tadalafil result in significant vasodilatory and antiproliferative effects [126-128]. Sildenafil has been demonstrated in patients with idiopathic pulmonary fibrosis and right ventricular dysfunction to improve quality of life and preservation of exercise capacity [88].

6.3.5. Soluble Guanylate Cyclase (sGC) Stimulators. A recent sGC stimulator, Riociguat, independently increases cGMP levels and improves WHO functional class, pulmonary vascular resistance, and serum markers of right ventricular stress [129].

6.3.6. Rho-Kinase (ROCK) Inhibitors. These hold significant promise for treatment of RHF in severe $\mathrm{PH}$ and their acute administration results in modest pulmonary vasodilation $[130,131]$. Their long-term effects on the right ventricular are unknown but a recent study of 74 patients who received fasudil, an intravenous rho-kinase inhibitor, demonstrated mortality benefits and reduced hospitalization and a favorable side effect profile [132]. The efficacy of statins and histone deacetylases in pulmonary hypertension has also been evaluated in multiple studies with limited success [133136].

6.3.7. Other Connective Tissue Disease Specific Therapies. Inhaled nitric oxide (iNO) has been studied to examine its effect on pulmonary vasoreactivity in patients with systemic sclerosis (SSc) who demonstrate pulmonary hypertension and right ventricular failure [137]. A study of 60 patients found no response to iNO in diffuse SSc. Though $40 \%$ of patients with vasoreactivity to iNO had pulmonary fibrosis, patients with no vasoreactivity more commonly exhibited fibrosis typical of diffuse scleroderma [137]. Decreased pulmonary pressures after administration of iNO were associated with subsequent improvement in right ventricular systolic function [137].

In patients with systemic lupus erythematosus-associated pulmonary arterial hypertension (SLE-PAH), intensive immunosuppressive therapy with intravenous cyclophosphamide and oral glucocorticoids has been demonstrated to decrease mPAP and improve hemodynamic parameters, sixminute-walk distance, and survival [138-141].

6.3.8. Emerging Treatment Options. Oral prostanoids such as Beraprost (twice daily dosing) and treprostinil (thrice daily dosing) have been evaluated as monotherapy with mixed results but are currently under investigation in various trials for their utility as combination therapies [122, 142, 143]. Selexipag, an oral, nonprostanoid selective IP receptor agonist, demonstrated a $39 \%$ reduction in time to first morbidity or mortality over a 4-year period and is currently being evaluated for its safety profile [144, 145]. Vardenafil, an oral PDE5 inhibitor, has been demonstrated to improve pulmonary hemodynamics and exercise capacity at 12 weeks while reducing oxidative stress. It however remains under investigation for treatment efficacy in patients with $\mathrm{PAH}$ $[146,147]$. Tyrosine kinase inhibitors such as imatinib have demonstrated treatment benefit in isolated cases, an effect that has not yet been replicated by several trials, some of which were discontinued due to severe side effects [148-155].

\section{Effects of Antifibrotic and Anti-Inflammatory Agents on Heart Failure in Idiopathic Pulmonary Fibrosis}

Two new agents have recently been approved for the treatment of patients with IPF. Pirfenidone is an oral antifibrotic agent with mechanisms of action that include the inhibition of key cytokines that mediate pathogenesis of inflammation and fibrosis [156]. Nintedanib is an oral intracellular inhibitor of tyrosine kinase that targets multiple growth factor receptors [157]. Both agents have been shown in multiple randomized controlled phase 3 trials to slow the rate of decline in lung function of patients with IPF $[156,157]$.

A multinational comprehensive evaluation of the longterm safety of pirfenidone in patients with idiopathic pulmonary fibrosis found no increased incidence in adverse cardiac events [158]. Interestingly, pirfenidone has been demonstrated in various animal models to attenuate myocardial fibrosis and left ventricular remodeling by inhibiting NLRP3-induced inflammation and subsequent fibrosis [159, $160]$, ultimately resulting in cardioprotective effects [161, 162]. However, these findings have not yet been demonstrated in human studies. Two large trials examining the efficacy and safety of nintedanib in patients with IPF did not demonstrate a significant increase in the incidence of cardiac adverse effects with the use of this medication [157].

\section{Right Ventricle-Targeted Therapies}

The initial cardiac hypertrophy, which occurs in response to the prolonged increase in pulmonary vascular pressure and altered hemodynamics, progressively becomes maladaptive and eventually results in decompensated ventricular function. As $\mathrm{PH}$ progresses, right ventricular dilation and fibrosis follow eventually resulting in functional right ventricular failure, the most common cause of death in patients with severe $\mathrm{PH}[24,163,164]$.

The persistently poor prognosis of patients with low right ventricular function despite therapies that effectively reduce the pulmonary vascular resistance highlights the crucial need for right ventricular-targeted therapies in these patients [165]. The underlying mechanisms of right ventricular failure are increasingly thought to differ from that of the left ventricle 
TABLE 1: Effects of pharmacologic therapies in patients with right ventricular dysfunction* .

\begin{tabular}{|c|c|c|c|c|}
\hline Medication & Route of administration & Mechanism of action & $\begin{array}{l}\text { Right ventricular } \\
\text { effect }\end{array}$ & Common side effects \\
\hline \multicolumn{5}{|l|}{$\begin{array}{l}\text { Therapies targeting pulmonary } \\
\text { hypertension }\end{array}$} \\
\hline Nifedipine and amlodipine & Oral & $\begin{array}{l}\text { Calcium channel } \\
\text { blockers }\end{array}$ & Reduce afterload & $\begin{array}{l}\text { Headache, dizziness, and } \\
\text { extremity edema }\end{array}$ \\
\hline $\begin{array}{l}\text { Bosentan, ambrisentan, and } \\
\text { macitentan }\end{array}$ & Oral & $\begin{array}{l}\text { Endothelin receptor } \\
\text { antagonists }\end{array}$ & Reduce afterload & $\begin{array}{l}\text { Headache, dizziness, and } \\
\text { arrhythmias }\end{array}$ \\
\hline Epoprostenol & IV & Prostacyclin analog & Reduces afterload & $\begin{array}{l}\text { Nausea, vomiting, } \\
\text { dizziness, and arrhythmias }\end{array}$ \\
\hline Iloprost & Inhaled & Prostacyclin analog & Reduces afterload & $\begin{array}{l}\text { Nausea, vomiting, } \\
\text { headache, and diarrhea }\end{array}$ \\
\hline Treprostinil & SC/IV/inhaled & Prostacyclin analog & Reduces afterload & $\begin{array}{l}\text { Nausea, headache, cough, } \\
\text { and dizziness }\end{array}$ \\
\hline Sildenafil and tadalafil & Oral & $\begin{array}{l}\text { Phosphodiesterase } \\
\text { type } 5 \text { inhibitors }\end{array}$ & Reduce afterload & $\begin{array}{l}\text { Nausea, vomiting, } \\
\text { headache, and tritanopia }\end{array}$ \\
\hline Riociguat & Oral & $\begin{array}{l}\text { Soluble guanylate } \\
\text { cyclase stimulator }\end{array}$ & $\begin{array}{l}\text { Reduces } \\
\text { hypertrophy }\end{array}$ & $\begin{array}{l}\text { Headache, dizziness, } \\
\text { gastritis, hypotension, and } \\
\text { diarrhea }\end{array}$ \\
\hline Imatinib & Oral & $\begin{array}{l}\text { Tyrosine kinase } \\
\text { inhibitor }\end{array}$ & Improves function & $\begin{array}{l}\text { Nausea, vomiting, edema, } \\
\text { diarrhea, rash, and } \\
\text { pancytopenia }\end{array}$ \\
\hline Fasudil & IV & Rho-kinase inhibitor & $\begin{array}{l}\text { Reduces } \\
\text { hypertrophy }\end{array}$ & $\begin{array}{l}\text { Nausea, renal dysfunction, } \\
\text { fever, and } \\
\text { thrombocytopenia }\end{array}$ \\
\hline Nitric oxide & Inhaled & $\begin{array}{l}\text { Pulmonary } \\
\text { vasodilator }\end{array}$ & Improves function & $\begin{array}{l}\text { Hypotension and } \\
\text { methemoglobinemia }\end{array}$ \\
\hline
\end{tabular}

Therapies targeting the right
ventricle (RV)

\begin{tabular}{|c|c|c|c|c|}
\hline Carvedilol and bisoprolol & Oral & $\begin{array}{l}\beta \text {-adrenergic receptor } \\
\text { blockers }\end{array}$ & $\begin{array}{l}\text { Decrease } \\
\text { myocardial fibrosis }\end{array}$ & $\begin{array}{l}\text { Dizziness, fatigue, diarrhea, } \\
\text { and hyperglycemia }\end{array}$ \\
\hline Ranolazine and trimetazidine & Oral & $\begin{array}{l}\text { Modulators of } \\
\text { metabolism }\end{array}$ & $\begin{array}{l}\text { Decrease } \\
\text { remodeling }\end{array}$ & $\begin{array}{l}\text { Nausea, headache, } \\
\text { dizziness, constipation, } \\
\text { edema, and dyspnea }\end{array}$ \\
\hline Ramipril & Oral & ACE inhibitor & $\begin{array}{l}\text { Decreases } \\
\text { myocardial fibrosis }\end{array}$ & $\begin{array}{l}\text { Nausea, vomiting, cough, } \\
\text { headache, and dizziness }\end{array}$ \\
\hline Protandim & Oral & Antioxidant & $\begin{array}{l}\text { Decreases } \\
\text { myocardial fibrosis }\end{array}$ & $\begin{array}{l}\text { Nausea, vomiting, rash, } \\
\text { headache, and diarrhea }\end{array}$ \\
\hline
\end{tabular}

Therapies targeting pulmonary fibrosis**

\begin{tabular}{|c|c|c|c|c|}
\hline Pirfenidone & Oral & Antifibrotic agent & $\begin{array}{l}\text { Decreases } \\
\text { myocardial fibrosis }\end{array}$ & $\begin{array}{l}\text { Nausea, vomiting, rash, } \\
\text { headache, diarrhea, and } \\
\text { dizziness }\end{array}$ \\
\hline Nintedanib & Oral & $\begin{array}{l}\text { Triple angiokinase } \\
\text { inhibitor }\end{array}$ & $\begin{array}{l}\text { Undetermined } \\
\text { direct effect }\end{array}$ & $\begin{array}{l}\text { Nausea, vomiting, } \\
\text { headache, diarrhea, and } \\
\text { anorexia }\end{array}$ \\
\hline
\end{tabular}

${ }^{*}$ None of these medications have been specifically approved for Group 3 pulmonary hypertension as these patients may have pulmonary fibrosis and may not demonstrate vasoreactivity. ${ }^{* *}$ Idiopathic pulmonary fibrosis, IV: intravenous, SC: subcutaneous.

and this may explain the variation in results across experimental therapies targeting both ventricles [166] (Table 1).

\subsection{Pharmacologic Agents}

8.1.1. $\beta$-Adrenoceptor ( $\beta$-AR) Blockers. Though downregulated $\beta$-adrenergic receptors and increased sympathetic activity are typical features of pulmonary arterial hypertension, use of these medications may decrease heart rate and myocardial contractility and result in systemic vasodilation limiting their unrestricted utility in these patients $[167,168]$. Patients with portopulmonary hypertension also demonstrate poor functional capacity and worse pulmonary hemodynamics with use of these medications [169]. Significant benefits such as reduction of myocardial oxygen consumption, restoration of effective $\mathrm{Ca}^{2+}$ transport, and prevention of arrhythmias 
TABLE 2: Trials of pulmonary hypertension therapies in idiopathic pulmonary fibrosis.

\begin{tabular}{|c|c|c|c|c|}
\hline Trial & Design & Medication/dose & Primary endpoint & Outcome \\
\hline $\begin{array}{l}\text { BUILD-1 } \\
\text { (Bosentan Use in } \\
\text { Interstitial Lung } \\
\text { Disease) }\end{array}$ & $\begin{array}{l}\text { Randomized, } \\
\text { double-blind, } \\
\text { placebo-controlled, } \\
\text { multicenter study }\end{array}$ & $\begin{array}{l}\text { Bosentan (oral) } \\
62.5 \mathrm{mg} \text { b.i.d. } \times \\
4 \text { wk., then } \\
125 \mathrm{mg} \text { b.i.d. } \geq \\
12 \mathrm{mth} \text {. }\end{array}$ & $\begin{array}{l}\text { 6-minute-walk } \\
\text { distance }\end{array}$ & $\begin{array}{l}\text { Bosentan showed no } \\
\text { superiority over placebo }\end{array}$ \\
\hline $\begin{array}{l}\text { STEP-IPF } \\
\text { (Sildenafil Trial of } \\
\text { Exercise Performance } \\
\text { in Idiopathic } \\
\text { Pulmonary Fibrosis) } \\
\end{array}$ & $\begin{array}{l}\text { Randomized, } \\
\text { double-blind, } \\
\text { placebo-controlled } \\
\text { trial }\end{array}$ & $\begin{array}{l}\text { Sildenafil (oral) } \\
20 \text { mg t.i.d. }\end{array}$ & $\begin{array}{l}\text { Proportion of patients } \\
\text { with } \geq 20 \% \text { increase in } \\
\text { 6-minute-walk } \\
\text { distance }\end{array}$ & $\begin{array}{l}\text { Sildenafil showed no } \\
\text { superiority over placebo } \\
\text { in primary outcome }\end{array}$ \\
\hline $\begin{array}{l}\text { BUILD-3 } \\
\text { (Bosentan Use in } \\
\text { Interstitial Lung } \\
\text { Disease) }\end{array}$ & $\begin{array}{l}\text { Prospective, } \\
\text { randomized, } \\
\text { double-blind, } \\
\text { placebo-controlled, } \\
\text { event-driven, } \\
\text { parallel-group trial }\end{array}$ & $\begin{array}{l}\text { Bosentan (oral) } \\
62.5 \mathrm{mg} \text { b.i.d. } \times \\
4 \text { wk., then } \\
125 \text { mg b.i.d., }\end{array}$ & $\begin{array}{l}\text { Time to IPF } \\
\text { worsening or death }\end{array}$ & $\begin{array}{l}\text { No significant difference } \\
\text { between treatment } \\
\text { groups }\end{array}$ \\
\hline $\begin{array}{l}\text { ARTEMIS-IPF } \\
\text { (Randomized, } \\
\text { Placebo-Controlled } \\
\text { Study to Evaluate } \\
\text { Safety and } \\
\text { Effectiveness of } \\
\text { Ambrisentan in IPF) } \\
\end{array}$ & $\begin{array}{l}\text { Randomized, } \\
\text { double-blind, } \\
\text { placebo-controlled, } \\
\text { event-driven phase } 3 \\
\text { trial }\end{array}$ & $\begin{array}{l}\text { Ambrisentan (oral) } \\
10 \text { mg daily }\end{array}$ & $\begin{array}{l}\text { Reduction in rate of } \\
\text { IPF progression }\end{array}$ & $\begin{array}{l}\text { Early study termination } \\
\text { due to worsening of lung } \\
\text { function decline and } \\
\text { increased respiratory } \\
\text { hospitalizations in } \\
\text { ambrisentan group }\end{array}$ \\
\hline $\begin{array}{l}\text { MUSIC } \\
\text { (Macitentan Use in an } \\
\text { Idiopathic Pulmonary } \\
\text { Fibrosis Clinical } \\
\text { Study) }\end{array}$ & $\begin{array}{l}\text { Prospective, } \\
\text { randomized, } \\
\text { double-blind, } \\
\text { multicenter, } \\
\text { placebo-controlled, } \\
\text { parallel-group phase } 2 \\
\text { trial }\end{array}$ & $\begin{array}{l}\text { Macitentan (oral) } \\
10 \text { mg daily }\end{array}$ & $\begin{array}{l}\text { Effect on forced vital } \\
\text { capacity }\end{array}$ & $\begin{array}{l}\text { No differences in } \\
\text { pulmonary function } \\
\text { tests or time to disease } \\
\text { progression or death }\end{array}$ \\
\hline $\begin{array}{l}\text { BPHIT } \\
\text { (Bosentan in } \\
\text { Pulmonary } \\
\text { Hypertension } \\
\text { Associated with } \\
\text { Fibrotic Idiopathic } \\
\text { Interstitial } \\
\text { Pneumonia) }\end{array}$ & $\begin{array}{l}\text { Randomized, } \\
\text { double-blind, } \\
\text { placebo-controlled } \\
\text { phase } 4 \text { study }\end{array}$ & $\begin{array}{l}\text { Bosentan (oral) } \\
62.5 \text { mg b.i.d. } \times \\
4 \text { wk., then } \\
125 \text { mg b.i.d. }\end{array}$ & $\begin{array}{l}\geq 20 \% \text { decrease from } \\
\text { baseline of pulmonary } \\
\text { vascular resistance } \\
\text { index over } 16 \text { weeks }\end{array}$ & $\begin{array}{l}\text { No difference in primary } \\
\text { outcome }\end{array}$ \\
\hline
\end{tabular}

may be achieved with the careful use of these medications $[170,171]$. Carvedilol, a selective $\beta 1$-AR blocker, improves right ventricular function and exercise tolerance and is described to exert cardioprotective effects [172-174]. Use of carvedilol has also been described in experimental models to improve biventricular fibrosis [175]. Bisoprolol has been shown in animal studies to improve right ventricular-arterial uncoupling and survival [176]. The therapeutic benefits of inhibition of $G$ protein-coupled receptor kinase-2 (GRK) mediated uncoupling of the $\beta$-adrenergic receptor have also been described with the use of Gallein, a novel small molecule that targets the G $\beta \gamma$ subunit of GRK2 $[177,178]$.

8.1.2. Angiotensin-Converting Enzyme (ACE) Inhibitors. The effect of ACE inhibitors on pulmonary hemodynamics and right ventricular function has not been evaluated by large studies. Limited data from case series yield conflicting results
$[179,180]$. Experimental animal models of ramipril describe an improvement in right ventricular systolic function [181].

8.1.3. Modulators of Metabolism. Progression of right ventricular failure is accompanied by downregulation of fatty acid oxidation, which may contribute to the mechanistic process [182, 183]. Metabolic modulators like ranolazine or trimetazidine have been demonstrated to mitigate the reduction in cardiac output with modest effects observed in right ventricular dysfunction $[166,183]$. Use of etomoxir, an inhibitor of fatty acid oxidation, has been shown to have equivocal results in right ventricular failure [184].

8.1.4. Antioxidants. Administration of protandim in experimental PH models has been shown to upregulate the expression of HO-1 (hemoxygenase-1), an isoenzyme that facilitates 
the production of antioxidant enzymes by promoting the expression of their genes $[166,185]$.

8.1.5. 5-Hydroxytryptamine-2B (5-HT2B) Receptor Antagonists. Murine models of pulmonary hypertension have demonstrated a significant role for 5-hydroxytryptamine (serotonin) in the development and progression of ventricular hypertrophy [186-188]. Terguride, a 5-HT2A and 5-HT2B receptor antagonist, and SB204741 (a 5-HT2B receptor antagonist) have been demonstrated to inhibit right ventricular fibrosis by reducing collagen deposition [189].

8.2. Nonpharmacologic Modalities. The efficacy of exercise rehabilitation and respiratory training in patients with pulmonary hypertension and heart failure has been studied and shown to improve exercise capacity, improve quality of life, and correct endothelial dysfunction [190, 191].

Cardiac resynchronization in PAH patients with ventricular dyssynchrony may correct the difference in duration of right ventricular contraction when compared to the left ventricle with subsequent improvement in right ventricular systolic function and diastolic relaxation [192-194]. Atrial septostomy may also be beneficial in severely ill patients with significantly elevated pressures by reducing the right ventricular preload $[195,196]$; therapy should however be individualized to each patient and limited to centers with expertise at performing this procedure [166]. Mechanical right ventricular support with extracorporeal membrane oxygenation (ECMO) and ventricular assist devices (VAD) may also be necessary for temporary circulatory support [197-199]. The CentriMag (a short-term continuous-flow pump) and PVAD (a long-term pneumatic pulsatile pump) are circulatory assist devices recently approved by the FDA for right ventricular support [200, 201]. The Impella RP approved for use in Europe is being evaluated for its safety and efficacy in the USA for support of cardiac function in patients with right ventricular failure [202, 203].

\section{Transplant for Treatment of Fibrotic Lung Disease}

Progression of advanced pulmonary fibrosis that remains refractory to medical management may eventually require single- or double-lung transplantation. A study of 821 recipients of lung transplant for pulmonary fibrosis showed significantly better early and late survival in recipients aged $<60$ years with single-lung transplant than bilateral lung transplant. Patients with IPF tend to be $>60$ years and in studies focused on IPF patients, double-lung transplant may be associated with equivalent or better long-term outcomes and graft survival than single-lung transplant [204, 205]; however unilateral transplant is an acceptable alternative and may affect the allocation process [206]. The preoperative mean PAP (<40 mmHg) has been demonstrated by multivariate analyses to be an independent risk factor for operative mortality $(\mathrm{OR}=9.7 ; p=0.01)[206]$; younger patients with significant pulmonary hypertension may benefit from receiving bilateral lung transplant [206]. Patients with severe PAH and right ventricular dysfunction may be considered for combined heart-lung transplantation [166].

\section{Conclusion and Future Directions}

The rising prevalence and mortality from fibrotic lung diseases create an urgent need for improved therapeutic strategies in the management of right ventricular failure and $\mathrm{PH}$ in patients with fibrotic lung disease, as there is a significant limitation of organs available for transplant. The poor resting gas exchange, low diffusing capacity of the lungs for carbon monoxide (DLCO), and cardiovascular mediated exercise limitation that characterize this unique group of patients contribute to the mechanisms driving progression of right ventricular dysfunction to failure. Individualized therapy should be instituted early and target the underlying lung disease as well as those specific mechanisms leading to right ventricular failure. As new treatment options emerge, clinical trials should focus on development of therapies with the most efficacy and improvement in quality of life while considering the effects on right ventricular function.

\section{Conflict of Interests}

The authors declare that there is no conflict of interests regarding the publication of this paper.

\section{Acknowledgment}

This research activity was supported by National Institutes of Health (NIH) Grant (T32 HL007605).

\section{References}

[1] A. U. Wells, M. Kokosi, and K. Karagiannis, "Treatment strategies for idiopathic interstitial pneumonias," Current Opinion in Pulmonary Medicine, vol. 20, no. 5, pp. 442-448, 2014.

[2] C. E. Daniels, E. S. Yi, and J. H. Ryu, "Autopsy findings in 42 consecutive patients with idiopathic pulmonary fibrosis," European Respiratory Journal, vol. 32, no. 1, pp. 170-174, 2008.

[3] A. K. Boutou, G. G. Pitsiou, I. Trigonis et al., "Exercise capacity in idiopathic pulmonary fibrosis: the effect of pulmonary hypertension," Respirology, vol. 16, no. 3, pp. 451-458, 2011.

[4] C. J. Lettieri, S. D. Nathan, S. D. Barnett, S. Ahmad, and A. F. Shorr, "Prevalence and outcomes of pulmonary arterial hypertension in advanced idiopathic pulmonary fibrosis," Chest, vol. 129, no. 3, pp. 746-752, 2006.

[5] O. A. Minai, J. F. Santacruz, J. M. Alster, M. M. Budev, and K. McCarthy, "Impact of pulmonary hemodynamics on 6-min walk test in idiopathic pulmonary fibrosis," Respiratory Medicine, vol. 106, no. 11, pp. 1613-1621, 2012.

[6] S. D. Nathan, O. A. Shlobin, S. Ahmad et al., "Serial development of pulmonary hypertension in patients with idiopathic pulmonary fibrosis," Respiration, vol. 76, no. 3, pp. 288-294, 2008.

[7] J. Behr and J. H. Ryu, "Pulmonary hypertension in interstitial lung disease," European Respiratory Journal, vol. 31, no. 6, pp. $1357-1367,2008$

[8] A. F. Shorr, J. L. Wainright, C. S. Cors, C. J. Lettieri, and S. D. Nathan, "Pulmonary hypertension in patients with pulmonary 
fibrosis awaiting lung transplant," European Respiratory Journal, vol. 30, no. 4, pp. 715-721, 2007.

[9] M. Kimura, H. Taniguchi, Y. Kondoh et al., "Pulmonary hypertension as a prognostic indicator at the initial evaluation in idiopathic pulmonary fibrosis," Respiration, vol. 85, no. 6, pp. 456-463, 2013.

[10] T. J. Corte, S. J. Wort, and A. U. Wells, "Pulmonary hypertension in idiopathic pulmonary fibrosis: a review," Sarcoidosis Vasculitis and Diffuse Lung Diseases, vol. 26, no. 1, pp. 7-19, 2009.

[11] V. Cottin, J. Le Pavec, G. Prévot et al., "Pulmonary hypertension in patients with combined pulmonary fibrosis and emphysema syndrome," European Respiratory Journal, vol. 35, no. 1, pp. 105111, 2010.

[12] E. Bossone, B. D. Bodini, A. Mazza, and L. Allegra, "Pulmonary arterial hypertension: the key role of echocardiography," Chest, vol. 127, no. 5, pp. 1836-1843, 2005.

[13] M. McGoon, D. Gutterman, V. Steen et al., "Screening, early detection, and diagnosis of pulmonary arterial hypertension: ACCP evidence-based clinical practice guidelines," Chest, vol. 126, no. 1, 2004.

[14] R. J. Barst, M. McGoon, A. Torbicki et al., "Diagnosis and differential assessment of pulmonary arterial hypertension," Journal of the American College of Cardiology, vol. 43, pp. 40S-47S, 2004.

[15] P. G. Yock and R. L. Popp, "Noninvasive estimation of right ventricular systolic pressure by Doppler ultrasound in patients with tricuspid regurgitation," Circulation, vol. 70, no. 4, pp. 657-662, 1984.

[16] I. Ben-Dor, M. R. Kramer, A. Raccah et al., "Echocardiography versus right-sided heart catheterization among lung transplantation candidates," Annals of Thoracic Surgery, vol. 81, no. 3, pp. 1056-1060, 2006.

[17] S. M. Arcasoy, J. D. Christie, V. A. Ferrari et al., "Echocardiographic assessment of pulmonary hypertension in patients with advanced lung disease," American Journal of Respiratory and Critical Care Medicine, vol. 167, no. 5, pp. 735-740, 2003.

[18] L. G. Rudski, W. W. Lai, J. Afilalo et al., "Guidelines for the echocardiographic assessment of the right heart in adults: a report from the American Society of Echocardiography endorsed by the European Association of Echocardiography, a registered branch of the European Society of Cardiology, and the Canadian Society of Echocardiography," Journal of the American Society of Echocardiography, vol. 23, pp. 685-713, 786-788, 2010.

[19] M. L. Alkotob, P. Soltani, M. A. Sheatt et al., "Reduced exercise capacity and stress-induced pulmonary hypertension in patients with scleroderma," Chest, vol. 130, no. 1, pp. 176-181, 2006.

[20] G. Pitsiou, C. E. Papadopoulos, H. I. Karvounis et al., "Utility of tissue doppler imaging in predicting outcome in patients with idiopathic pulmonary fibrosis," Hellenic Journal of Cardiology, vol. 48, no. 3, pp. 143-151, 2007.

[21] T. S. Saba, J. Foster, M. Cockburn, M. Cowan, and A. J. Peacock, "Ventricular mass index using magnetic resonance imaging accurately estimates pulmonary artery pressure," European Respiratory Journal, vol. 20, no. 6, pp. 1519-1524, 2002.

[22] L. J. M. Kroft, P. Simons, J. M. van Laar, and A. de Roos, "Patients with pulmonary fibrosis: cardiac function assessed with MR imaging," Radiology, vol. 216, no. 2, pp. 464-471, 2000.

[23] A. M. Groves, T. Win, S. C. Charman, C. Wisbey, J. Pepke-Zaba, and R. A. Coulden, "Semi-quantitative assessment of tricuspid regurgitation on contrast-enhanced multidetector CT," Clinical Radiology, vol. 59, no. 8, pp. 715-719, 2004.
[24] N. F. Voelkel, R. A. Quaife, L. A. Leinwand et al., "Right ventricular function and failure: report of a National Heart, Lung, and Blood Institute working group on cellular and molecular mechanisms of right heart failure," Circulation, vol. 114, no. 17, pp. 1883-1891, 2006.

[25] J.-L. Vachiéry, Y. Adir, J. A. Barberà et al., "Pulmonary hypertension due to left heart diseases," Journal of the American College of Cardiology, vol. 62, no. 25, pp. D100-D108, 2013.

[26] J. Aguero, K. Ishikawa, L. Hadri et al., "Characterization of right ventricular remodeling and failure in a chronic pulmonary hypertension model," The American Journal of PhysiologyHeart and Circulatory Physiology, vol. 307, no. 8, pp. H1204H1215, 2014.

[27] Y.-Y. Zhao, Y. Liu, R.-V. Stan et al., "Defects in caveolin-1 cause dilated cardiomyopathy and pulmonary hypertension in knockout mice," Proceedings of the National Academy of Sciences of the United States of America, vol. 99, no. 17, pp. 11375-11380, 2002.

[28] K. Node, M. Kitakaze, H. Kosaka et al., "Increased release of NO during ischemia reduces myocardial contractility and improves metabolic dysfunction," Circulation, vol. 93, no. 2, pp. 356-364, 1996.

[29] M. S. Finkel, C. V. Oddis, T. D. Jacob, S. C. Watkins, B. G. Hattler, and R. L. Simmons, "Negative inotropic effects of cytokines on the heart mediated by nitric oxide," Science, vol. 257, no. 5068, pp. 387-389, 1992.

[30] D.-L. Dixon, K. M. Griggs, A. D. Bersten, and C. G. De Pasquale, "Systemic inflammation and cell activation reflects morbidity in chronic heart failure," Cytokine, vol. 56, no. 3, pp. 593-599, 2011.

[31] E. Fireman, N. Vardinon, M. Burke et al., "Predictive value of response to treatment of T-lymphocyte subpopulations in idiopathic pulmonary fibrosis," European Respiratory Journal, vol. 11, no. 3, pp. 706-711, 1998.

[32] T. Tanabe, S. Kanoh, W. B. Moskowitz, and B. K. Rubin, "Cardiac asthma: transforming growth factor- $\beta$ from the failing heart leads to squamous metaplasia in human airway cells and in the murine lung," Chest, vol. 142, no. 5, pp. 1274-1283, 2012.

[33] J. Agustin Cruz, E. M. Bauer, A. I. Rodriguez et al., "Chronic hypoxia induces right heart failure in caveolin- $1^{-/-}$mice," The American Journal of Physiology-Heart and Circulatory Physiology, vol. 302, no. 12, pp. H2518-H2527, 2012.

[34] W. Steudel, M. Scherrer-Crosbie, K. D. Bloch et al., "Sustained pulmonary hypertension and right ventricular hypertrophy after chronic hypoxia in mice with congenital deficiency of nitric oxide synthase," The Journal of Clinical Investigation, vol. 101, no. 11, pp. 2468-2477, 1998.

[35] S.-F. Yet, M. A. Perrella, M. D. Layne et al., "Hypoxia induces severe right ventricular dilatation and infarction in heme oxygenase-1 null mice," The Journal of Clinical Investigation, vol. 103, no. 8, pp. R23-R29, 1999.

[36] A. Adegunsoye and S. Ramachandran, "Etiopathogenetic mechanisms of pulmonary hypertension in sleep-related breathing disorders," Pulmonary Medicine, vol. 2012, Article ID 273591, 10 pages, 2012.

[37] N. Hama, H. Itoh, G. Shirakami et al., "Rapid ventricular induction of brain natriuretic peptide gene expression in experimental acute myocardial infarction," Circulation, vol. 92, no. 6, pp. 1558-1564, 1995.

[38] A. Fijalkowska, M. Kurzyna, A. Torbicki et al., "Serum N-terminal brain natriuretic peptide as a prognostic parameter in patients with pulmonary hypertension," Chest, vol. 129 , no. 5, pp. 1313-1321, 2006. 
[39] H. H. Leuchte, M. El Nounou, J. C. Tuerpe et al., "N-terminal pro-brain natriuretic peptide and renal insufficiency as predictors of mortality in pulmonary hypertension," Chest, vol. 131, no. 2, pp. 402-409, 2007.

[40] K. G. Blyth, B. A. Groenning, P. B. Mark et al., "NT-proBNP can be used to detect right ventricular systolic dysfunction in pulmonary hypertension," European Respiratory Journal, vol. 29, no. 4, pp. 737-744, 2007.

[41] K. Jatti, R. Paisey, and R. More, "Coronary artery disease in Alström syndrome," European Journal of Human Genetics, vol. 20, no. 1, pp. 117-118, 2012.

[42] M. A. Loudon, N. G. Bellenger, C. M. Carey, and R. B. Paisey, "Cardiac magnetic resonance imaging in Alström syndrome," Orphanet Journal of Rare Diseases, vol. 4, no. 1, article 14, 2009.

[43] D. Mozaffarian, E. J. Benjamin, A. S. Go et al., "Heart disease and stroke statistics-2015 update: a report from the American Heart Association," Circulation, vol. 131, no. 4, pp. e29-e322, 2015.

[44] D. D. Schocken, E. J. Benjamin, G. C. Fonarow et al., "Prevention of heart failure: a scientific statement from the American Heart Association Councils on epidemiology and prevention, clinical cardiology, cardiovascular nursing, and high blood pressure research; Quality of Care and Outcomes Research Interdisciplinary Working Group; and Functional Genomics and Translational Biology Interdisciplinary Working Group," Circulation, vol. 117, no. 19, pp. 2544-2565, 2008.

[45] P. A. McCullough, E. F. Philbin, J. A. Spertus, S. Kaatz, K. R. Sandberg, and W. D. Weaver, "Confirmation of a heart failure epidemic: findings from the Resource Utilization Among Congestive Heart Failure (REACH) study," Journal of the American College of Cardiology, vol. 39, no. 1, pp. 60-69, 2002.

[46] A. L. Bui, T. B. Horwich, and G. C. Fonarow, "Epidemiology and risk profile of heart failure," Nature Reviews Cardiology, vol. 8, no. 1, pp. 30-41, 2011.

[47] D. S. Kim, "Acute exacerbations in patients with idiopathic pulmonary fibrosis," Respiratory Research, vol. 14, article 86, 2013.

[48] B. Ley, H. R. Collard, and T. E. King Jr., "Clinical course and prediction of survival in idiopathic pulmonary fibrosis," American Journal of Respiratory and Critical Care Medicine, vol. 183, no. 4, pp. 431-440, 2011.

[49] K. Kee and M. T. Naughton, "Heart failure and the lung," Circulation Journal, vol. 74, no. 12, pp. 2507-2516, 2010.

[50] J.-F. Jasmin, A. Calderone, T.-K. Leung, L. Villeneuve, and J. Dupuis, "Lung structural remodeling and pulmonary hypertension after myocardial infarction: complete reversal with irbesartan," Cardiovascular Research, vol. 58, no. 3, pp. 621-631, 2003.

[51] W. Huang, M. P. Kingsbury, M. A. Turner, J. L. Donnelly, N. A. Flores, and D. J. Sheridan, "Capillary filtration is reduced in lungs adapted to chronic heart failure: morphological and haemodynamic correlates," Cardiovascular Research, vol. 49, no. 1, pp. 207-217, 2001.

[52] K. Tsukimoto, O. Mathieu-Costello, R. Prediletto, A. R. Elliott, and J. B. West, "Ultrastructural appearances of pulmonary capillaries at high transmural pressures," Journal of Applied Physiology, vol. 71, no. 2, pp. 573-582, 1991.

[53] M. L. Costello, O. Mathieu-Costello, and J. B. West, "Stress failure of alveolar epithelial cells studied by scanning electron microscopy," American Review of Respiratory Disease, vol. 145, no. 6, pp. 1446-1455, 1992.

[54] S. Nanjo, Y. Yamashiro, S. Fujimoto et al., "Evaluation of sympathetic activity by ${ }^{123}$ I-metaiodobenzylguanidine myocardial scintigraphy in dilated cardiomyopathy patients with sleep breathing disorder," Circulation Journal, vol. 73, no. 4, pp. 686690, 2009.

[55] S. Javaheri, R. Shukla, H. Zeigler, and L. Wexler, "Central sleep apnea, right ventricular dysfunction, and low diastolic blood pressure are predictors of mortality in systolic heart failure," Journal of the American College of Cardiology, vol. 49, no. 20, pp. 2028-2034, 2007.

[56] S. Javaheri, "Sleep disorders in systolic heart failure: a prospective study of 100 male patients. The final report," International Journal of Cardiology, vol. 106, no. 1, pp. 21-28, 2006.

[57] D. D. Sin, F. Fitzgerald, J. D. Parker, G. Newton, J. S. Floras, and T. D. Bradley, "Risk factors for central and obstructive sleep apnea in 450 men and women with congestive heart failure," American Journal of Respiratory and Critical Care Medicine, vol. 160, no. 4, pp. 1101-1106, 1999.

[58] H. W. Duchna, "Sleep-related breathing disorders-a second edition of the International Classification of Sleep Disorders (ICSD-2) of the American Academy of Sleep Medicine (AASM)," Pneumologie, vol. 60, pp. 568-575, 2006.

[59] M. J. Sateia, "International classification of sleep disorders-third edition: highlights and modifications," Chest, vol. 146, no. 5, pp. 1387-1394, 2014.

[60] K. Rasche and M. Orth, "Sleep and breathing in idiopathic pulmonary fibrosis," Journal of Physiology and Pharmacology, vol. 60, supplement 5, pp. 13-14, 2009.

[61] R. W. Light and R. B. George, "Serial pulmonary function in patients with acute heart failure," Archives of Internal Medicine, vol. 143, no. 3, pp. 429-433, 1983.

[62] K. K. Iversen, J. Kjaergaard, D. Akkan et al., "Chronic obstructive pulmonary disease in patients admitted with heart failure," Journal of Internal Medicine, vol. 264, no. 4, pp. 361-369, 2008.

[63] K. K. Iversen, J. Kjaergaard, D. Akkan et al., "The prognostic importance of lung function in patients admitted with heart failure," European Journal of Heart Failure, vol. 12, no. 7, pp. 685691, 2010.

[64] T. P. Olson, K. C. Beck, J. B. Johnson, and B. D. Johnson, “Competition for intrathoracic space reduces lung capacity in patients with chronic heart failure: a radiographic study," Chest, vol. 130, no. 1, pp. 164-171, 2006.

[65] T. J. Huie, A. L. Olson, G. P. Cosgrove et al., "A detailed evaluation of acute respiratory decline in patients with fibrotic lung disease: aetiology and outcomes," Respirology, vol. 15, no. 6, pp. 909-917, 2010.

[66] V. Ambrosini, A. Cancellieri, M. Chilosi et al., "Acute exacerbation of idiopathic pulmonary fibrosis: report of a series," European Respiratory Journal, vol. 22, no. 5, pp. 821-826, 2003.

[67] A. Churg, N. L. Müller, C. I. S. Silva, and J. L. Wright, "Acute exacerbation (acute lung injury of unknown cause) in UIP and other forms of fibrotic interstitial pneumonias," The American Journal of Surgical Pathology, vol. 31, no. 2, pp. 277-284, 2007.

[68] I.-N. Park, D. S. Kim, T. S. Shim et al., "Acute exacerbation of interstitial pneumonia other than idiopathic pulmonary fibrosis," Chest, vol. 132, no. 1, pp. 214-220, 2007.

[69] Y. Miyazaki, T. Tateishi, T. Akashi, Y. Ohtani, N. Inase, and Y. Yoshizawa, "Clinical predictors and histologic appearance of acute exacerbations in chronic hypersensitivity pneumonitis," Chest, vol. 134, no. 6, pp. 1265-1270, 2008.

[70] T. Suda, Y. Kaida, Y. Nakamura et al., "Acute exacerbation of interstitial pneumonia associated with collagen vascular diseases," Respiratory Medicine, vol. 103, no. 6, pp. 846-853, 2009. 
[71] A. L. Olson, T. J. Huie, S. D. Groshong et al., "Acute exacerbations of fibrotic hypersensitivity pneumonitis: a case series," Chest, vol. 134, no. 4, pp. 844-850, 2008.

[72] F. Luppi, S. Cerri, S. Taddei, G. Ferrara, and V. Cottin, "Acute exacerbation of idiopathic pulmonary fibrosis: a clinical review," Internal and Emergency Medicine, vol. 10, no. 4, pp. 401-411, 2015.

[73] M. Rabinovitch, "Pulmonary hypertension: updating a mysterious disease," Cardiovascular Research, vol. 34, no. 2, pp. 268272, 1997.

[74] M. Humbert, O. Sitbon, and G. Simonneau, "Treatment of pulmonary arterial hypertension," The New England Journal of Medicine, vol. 351, no. 14, pp. 1425-1473, 2004.

[75] P. Steele, G. Strange, J. Wlodarczyk et al., "Hemodynamics in pulmonary arterial hypertension (PAH): do they explain longterm clinical outcomes with PAH-specific therapy?" BMC Cardiovascular Disorders, vol. 10, article 9, 2010.

[76] A. Campo, S. C. Mathai, J. Le Pavec et al., "Outcomes of hospitalisation for right heart failure in pulmonary arterial hypertension," European Respiratory Journal, vol. 38, no. 2, pp. 359367, 2011.

[77] B. Sztrymf, R. Souza, L. Bertoletti et al., "Prognostic factors of acute heart failure in patients with pulmonary arterial hypertension," European Respiratory Journal, vol. 35, no. 6, pp. 1286-1293, 2010.

[78] F. Haddad, T. Peterson, E. Fuh et al., "Characteristics and outcome after hospitalization for acute right heart failure in patients with pulmonary arterial hypertension," Circulation: Heart Failure, vol. 4, no. 6, pp. 692-699, 2011.

[79] J. T. Shin and M. J. Semigran, "Heart failure and pulmonary hypertension," Heart Failure Clinics, vol. 6, no. 2, pp. 215-222, 2010.

[80] N. Galie, M. M. Hoeper, M. Humbert et al., "Guidelines for the diagnosis and treatment of pulmonary hypertension: the Task Force for the Diagnosis and Treatment of Pulmonary Hypertension of the European Society of Cardiology (ESC) and the European Respiratory Society (ERS), endorsed by the International Society of Heart and Lung Transplantation (ISHLT)," European Heart Journal, vol. 30, pp. 2493-2537, 2009.

[81] N. Galiè, P. A. Corris, A. Frost et al., "Updated treatment algorithm of pulmonary arterial hypertension," Journal of the American College of Cardiology, vol. 62, no. 25, pp. D60-D72, 2013.

[82] W. Seeger, Y. Adir, J. A. Barberà et al., "Pulmonary hypertension in chronic lung diseases," Journal of the American College of Cardiology, vol. 62, no. 25, pp. D109-D116, 2013.

[83] T. E. King Jr., J. Behr, K. K. Brown et al., "BUILD-1: a randomized placebo-controlled trial of bosentan in idiopathic pulmonary fibrosis," American Journal of Respiratory and Critical Care Medicine, vol. 177, no. 1, pp. 75-81, 2008.

[84] T. E. King Jr., K. K. Brown, G. Raghu et al., "BUILD-3: a randomized, controlled trial of bosentan in idiopathic pulmonary fibrosis," American Journal of Respiratory and Critical Care Medicine, vol. 184, no. 1, pp. 92-99, 2011.

[85] G. Raghu, R. Million-Rousseau, A. Morganti et al., "Macitentan for the treatment of idiopathic pulmonary fibrosis: the randomised controlled MUSIC trial," European Respiratory Journal, vol. 42, no. 6, pp. 1622-1632, 2013.

[86] G. Raghu, J. Behr, K. K. Brown et al., "Treatment of idiopathic pulmonary fibrosis with ambrisentan: a parallel, randomized trial," Annals of Internal Medicine, vol. 158, no. 9, pp. 641-649, 2013.
[87] T. J. Corte, G. J. Keir, K. Dimopoulos et al., "Bosentan in pulmonary hypertension associated with fibrotic idiopathic interstitial pneumonia," American Journal of Respiratory and Critical Care Medicine, vol. 190, no. 2, pp. 208-217, 2014.

[88] M. K. Han, D. S. Bach, P. G. Hagan et al., "Sildenafil preserves exercise capacity in patients with idiopathic pulmonary fibrosis and right-sided ventricular dysfunction," Chest, vol. 143, pp. 1699-1708, 2013.

[89] M. M. Hoeper, M. Halank, H. Wilkens et al., "Riociguat for interstitial lung disease and pulmonary hypertension: a pilot trial," European Respiratory Journal, vol. 41, no. 4, pp. 853-860, 2013.

[90] G. Raghu, B. Rochwerg, Y. Zhang et al., "An official ATS/ERS/ JRS/ALAT Clinical Practice Guideline: treatment of idiopathic pulmonary fibrosis. An Update of the 2011 Clinical Practice Guideline," American Journal of Respiratory and Critical Care Medicine, vol. 192, no. 2, pp. e3-e19, 2015.

[91] G. Raghu, H. R. Collard, J. J. Egan et al., "An official ATS/ERS/ JRS/ALAT statement: idiopathic pulmonary fibrosis: evidencebased guidelines for diagnosis and management," American Journal of Respiratory and Critical Care Medicine, vol. 183, no. 6, pp. 788-824, 2011.

[92] N. Demir, A. Şahin, O. Küçükşahin et al., "Pulmonary arterial hypertension and systemic sclerosis relation: a single centre experience," Heart Lung and Circulation, vol. 23, no. 7, pp. 667673, 2014.

[93] J. Le Pavec, R. E. Girgis, N. Lechtzin et al., "Systemic sclerosisrelated pulmonary hypertension associated with interstitial lung disease: impact of pulmonary arterial hypertension therapies," Arthritis \& Rheumatism, vol. 63, no. 8, pp. 2456-2464, 2011.

[94] H.-A. Ghofrani, A. M. D’Armini, F. Grimminger et al., "Riociguat for the treatment of chronic thromboembolic pulmonary hypertension," The New England Journal of Medicine, vol. 369, no. 4, pp. 319-329, 2013.

[95] H.-A. Ghofrani, N. Galiè, F. Grimminger et al., "Riociguat for the treatment of pulmonary arterial hypertension," The New England Journal of Medicine, vol. 369, no. 4, pp. 330-340, 2013.

[96] H. A. Ghofrani, M. M. Hoeper, M. Halank et al., "Riociguat for chronic thromboembolic pulmonary hypertension and pulmonary arterial hypertension: a phase II study," European Respiratory Journal, vol. 36, no. 4, pp. 792-799, 2010.

[97] F. Grimminger, G. Weimann, R. Frey et al., "First acute haemodynamic study of soluble guanylate cyclase stimulator riociguat in pulmonary hypertension," European Respiratory Journal, vol. 33, no. 4, pp. 785-792, 2009.

[98] S. Rich, E. Kaufmann, and P. S. Levy, "The effect of high doses of calcium-channel blockers on survival in primary pulmonary hypertension," The New England Journal of Medicine, vol. 327, no. 2, pp. 76-81, 1992.

[99] D. Giannessi, S. Del Ry, and R. L. Vitale, "The role of endothelins and their receptors in heart failure," Pharmacological Research, vol. 43, no. 2, pp. 111-126, 2001.

[100] R. J. Cody, G. J. Haas, P. F. Binkley, Q. Capers, and R. Kelley, "Plasma endothelin correlates with the extent of pulmonary hypertension in patients with chronic congestive heart failure," Circulation, vol. 85, no. 2, pp. 504-509, 1992.

[101] S. Sakai, T. Miyauchi, T. Sakurai et al., "Endogenous endothelin1 participates in the maintenance of cardiac function in rats with congestive heart failure: marked increase in endothelin-1 production in the failing heart," Circulation, vol. 93, no. 6, pp. 1214-1222, 1996. 
[102] D. J. Stewart, R. D. Levy, P. Cernacek, and D. Langleben, "Increased plasma endothelin-1 in pulmonary hypertension: marker or mediator of disease?" Annals of Internal Medicine, vol. 114, no. 6, pp. 464-469, 1991.

[103] P. I. Anand, P. J. McMurray, P. J. N. Cohn et al., "Long-term effects of darusentan on left-ventricular remodelling and clinical outcomes in the EndothelinA Receptor Antagonist Trial in Heart Failure (EARTH): randomised, double-blind, placebocontrolled trial," The Lancet, vol. 364, no. 9431, pp. 347-354, 2004.

[104] R. N. Channick, G. Simonneau, O. Sitbon et al., "Effects of the dual endothelin-receptor antagonist bosentan in patients with pulmonary hypertension: a randomised placebo-controlled study," The Lancet, vol. 358, no. 9288, pp. 1119-1123, 2001.

[105] N. Galiè, L. Rubin, M. Hoeper et al., “Treatment of patients with mildly symptomatic pulmonary arterial hypertension with bosentan (EARLY study): a double-blind, randomised controlled trial," The Lancet, vol. 371, no. 9630, pp. 2093-2100, 2008.

[106] M. Humbert, E. S. Segal, D. G. Kiely, J. Carlsen, B. Schwierin, and M. M. Hoeper, "Results of European post-marketing surveillance of bosentan in pulmonary hypertension," European Respiratory Journal, vol. 30, no. 2, pp. 338-344, 2007.

[107] A. M. Wolfson, N. Steiger, and M. Gomberg-Maitland, "New pharmacotherapies for pulmonary hypertension: where do they fit in?" Current Hypertension Reports, vol. 16, no. 12, pp. 1-10, 2014.

[108] O. Ben-Yehuda, D. Pizzuti, A. Brown et al., "Long-term hepatic safety of ambrisentan in patients with pulmonary arterial hypertension," Journal of the American College of Cardiology, vol. 60 , no. 1, pp. 80-81, 2012.

[109] N. Galiè, H. Olschewski, R. J. Oudiz et al., "Ambrisentan for the treatment of pulmonary arterial hypertension: results of the ambrisentan in pulmonary arterial hypertension, randomized, double-blind, placebo-controlled, multicenter, efficacy (ARIES) study 1 and 2," Circulation, vol. 117, no. 23, pp. 3010-3019, 2008.

[110] T. Pulido, I. Adzerikho, R. N. Channick et al., "Macitentan and morbidity and mortality in pulmonary arterial hypertension," The New England Journal of Medicine, vol. 369, no. 9, pp. 809818, 2013.

[111] H. Olschewski, F. Rose, R. Schermuly et al., "Prostacyclin and its analogues in the treatment of pulmonary hypertension," Pharmacology and Therapeutics, vol. 102, no. 2, pp. 139-153, 2004.

[112] Y. Yui, H. Nakajima, C. Kawai, and T. Murakami, "Prostacyclin therapy in patients with congestive heart failure," The American Journal of Cardiology, vol. 50, no. 2, pp. 320-324, 1982.

[113] O. Sitbon, M. Humbert, H. Nunes et al., "Long-term intravenous epoprostenol infusion in primary pulmonary hypertension: prognostic factors and survival," Journal of the American College of Cardiology, vol. 40, no. 4, pp. 780-788, 2002.

[114] V. V. McLaughlin, A. Shillington, and S. Rich, "Survival in primary pulmonary hypertension: the impact of epoprostenol therapy," Circulation, vol. 106, no. 12, pp. 1477-1482, 2002.

[115] R. Agarwal and M. Gomberg-Maitland, "Current therapeutics and practical management strategies for pulmonary arterial hypertension," American Heart Journal, vol. 162, no. 2, pp. 201213, 2011.

[116] K. M. Chin, D. B. Badesch, I. M. Robbins et al., "Two formulations of epoprostenol sodium in the treatment of pulmonary

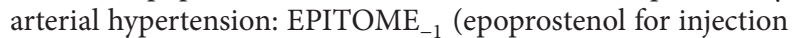
in pulmonary arterial hypertension), a phase IV, open-label, randomized study," American Heart Journal, vol. 167, no. 2, pp. 218-225.el, 2014.

[117] G. Simonneau, R. J. Barst, N. Galie et al., "Continuous subcutaneous infusion of treprostinil, a prostacyclin analogue, in patients with pulmonary arterial hypertension: a double-blind, randomized, placebo-controlled trial," American Journal of Respiratory and Critical Care Medicine, vol. 165, no. 6, pp. 800804, 2002.

[118] R. J. Barst, N. Galie, R. Naeije et al., "Long-term outcome in pulmonary arterial hypertension patients treated with subcutaneous treprostinil," European Respiratory Journal, vol. 28, no. 6, pp. 1195-1203, 2006.

[119] V. F. Tapson, M. Gomberg-Maitland, V. V. McLaughlin et al., "Safety and efficacy of IV treprostinil for pulmonary arterial hypertension: a prospective, multicenter, open-label, 12-week trial," Chest, vol. 129, no. 3, pp. 683-688, 2006.

[120] H. Olschewski, G. Simonneau, N. Galiè et al., "Inhaled iloprost for severe pulmonary hypertension," The New England Journal of Medicine, vol. 347, no. 5, pp. 322-329, 2002.

[121] Y. Wu, D. S. O'Callaghan, and M. Humbert, "An update on medical therapy for pulmonary arterial hypertension," Current Hypertension Reports, vol. 15, no. 6, pp. 614-622, 2013.

[122] R. J. Barst, M. McGoon, V. McLaughlin et al., "Beraprost therapy for pulmonary arterial hypertension," Journal of the American College of Cardiology, vol. 41, pp. 2119-2125, 2003.

[123] C. A. Sueta, M. Gheorghiade, K. F. Adams Jr. et al., "Safety and efficacy of epoprostenol in patients with severe congestive heart failure. Epoprostenol Multicenter Research Group," The American Journal of Cardiology, vol. 75, no. 3, pp. 34A-43A, 1995.

[124] R. M. Califf, K. F. Adams, W. J. McKenna, and et al, "A randomized controlled trial of epoprostenol therapy for severe congestive heart failure: the Flolan International Randomized Survival Trial (FIRST)," The American Heart Journal, vol. 134, no. 1, pp. 44-54, 1997.

[125] S. I. McFarlane, N. Winer, and J. R. Sowers, "Role of the natriuretic peptide system in cardiorenal protection," Archives of Internal Medicine, vol. 163, no. 22, pp. 2696-2704, 2003.

[126] N. Galiè, H. A. Ghofrani, A. Torbicki et al., "Sildenafil citrate therapy for pulmonary arterial hypertension," The New England Journal of Medicine, vol. 353, no. 20, pp. 2148-2157, 2005.

[127] R. B. Moreland, I. Goldstein, N. N. Kim, and A. Traish, "Sildenafil citrate, a selective phosphodiesterase type 5 inhibitor: research and clinical implications in erectile dysfunction," Trends in Endocrinology and Metabolism, vol. 10, no. 3, pp. 97104, 1999.

[128] N. Galiè, B. H. Brundage, H. A. Ghofrani et al., “Tadalafil therapy for pulmonary arterial hypertension," Circulation, vol. 119, no. 22, pp. 2894-2903, 2009.

[129] A. Dasgupta, L. Bowman, C. D’Arsigny, and S. Archer, "Soluble guanylate cyclase: a new therapeutic target for pulmonary arterial hypertension and chronic thromboembolic pulmonary hypertension," Clinical Pharmacology \& Therapeutics, vol. 97, no. 1, pp. 88-102, 2015.

[130] Y. Fukumoto, T. Matoba, A. Ito et al., "Acute vasodilator effects of a Rho-kinase inhibitor, fasudil, in patients with severe pulmonary hypertension," Heart, vol. 91, no. 3, pp. 391-392, 2005.

[131] K. Ishikura, N. Yamada, M. Ito et al., "Beneficial acute effects of Rho-kinase inhibitor in patients with pulmonary arterial hypertension," Circulation Journal, vol. 70, no. 2, pp. 174-178, 2006. 
[132] R. Jiang, Z. S. Ai, X. Jiang et al., "Intravenous fasudil improves in-hospital mortality of patients with right heart failure in severe pulmonary hypertension," Hypertension Research, vol. 38, no. 8, pp. 539-544, 2015.

[133] L. Taraseviciene-Stewart, R. Scerbavicius, K.-H. Choe et al., "Simvastatin causes endothelial cell apoptosis and attenuates severe pulmonary hypertension," American Journal of Physiology_Lung Cellular and Molecular Physiology, vol. 291, no. 4, pp. L668-L676, 2006.

[134] S. M. Kawut, E. Bagiella, D. J. Lederer et al., "Randomized clinical trial of aspirin and simvastatin for pulmonary arterial hypertension: ASA-STAT," Circulation, vol. 123, no. 25, pp. 2985-2993, 2011.

[135] L. Zhao, C.-N. Chen, N. Hajji et al., "Histone deacetylation inhibition in pulmonary hypertension: therapeutic potential of valproic acid and suberoylanilide hydroxamic acid," Circulation, vol. 126, no. 4, pp. 455-467, 2012.

[136] H. J. Bogaard, S. Mizuno, A. A. Al Hussaini et al., "Suppression of histone deacetylases worsens right ventricular dysfunction after pulmonary artery banding in rats," American Journal of Respiratory and Critical Care Medicine, vol. 183, no. 10, pp. 14021410, 2011.

[137] W. Plazak, K. Gryga, J. Sznajd et al., "Reactivity of pulmonary circulation and right ventricle function to inhaled nitric oxide in systemic sclerosis patients," Clinical Rheumatology, vol. 31, no. 1, pp. 99-104, 2012.

[138] S. Miyamichi-Yamamoto, Y. Fukumoto, K. Sugimura et al., "Intensive immunosuppressive therapy improves pulmonary hemodynamics and long-term prognosis in patients with pulmonary arterial hypertension associated with connective tissue disease," Circulation Journal, vol. 75, no. 11, pp. 2668-2674, 2011.

[139] X. Jais, D. Launay, A. Yaici et al., "Immunosuppressive therapy in lupus- and mixed connective tissue disease-associated pulmonary arterial hypertension: a retrospective analysis of twenty-three cases," Arthritis \& Rheumatism, vol. 58, no. 2, pp. 521-531, 2008.

[140] O. Sanchez, O. Sitbon, X. Jaï'S, G. Simonneau, and M. Humbert, "Immunosuppressive therapy in connective tissue diseasesassociated pulmonary arterial hypertension," Chest, vol. 130, no. 1, pp. 182-189, 2006.

[141] A. Dhala, "Pulmonary arterial hypertension in systemic lupus erythematosus: current status and future direction," Clinical and Developmental Immunology, vol. 2012, Article ID 854941, 12 pages, 2012.

[142] N. Galiè, M. Humbert, J.-L. Vachiéry et al., "Effects of beraprost sodium, an oral prostacyclin analogue, in patients with pulmonary arterial hypertension: a randomized, double-blind, placebo-controlled trial," Journal of the American College of Cardiology, vol. 39, no. 9, pp. 1496-1502, 2002.

[143] Z.-C. Jing, K. Parikh, T. Pulido et al., "Efficacy and safety of oral treprostinil monotherapy for the treatment of pulmonary arterial hypertension: a randomized, controlled trial," Circulation, vol. 127, no. 5, pp. 624-633, 2013.

[144] N. Skoro-Sajer and I. M. Lang, "Selexipag for the treatment of pulmonary arterial hypertension," Expert Opinion on Pharmacotherapy, vol. 15, no. 3, pp. 429-436, 2014.

[145] S. Bruderer, N. Hurst, P. Kaufmann, and J. Dingemanse, "Multiple-dose up-titration study to evaluate the safety, tolerability, pharmacokinetics, and pharmacodynamics of selexipag, an orally available selective prostacyclin receptor agonist, in healthy subjects," Pharmacology, vol. 94, no. 3-4, pp. 148-156, 2014.
[146] Z.-C. Jing, Z.-X. Yu, J.-Y. Shen et al., "Vardenafil in pulmonary arterial hypertension: a randomized, double-blind, placebocontrolled study," American Journal of Respiratory and Critical Care Medicine, vol. 183, no. 12, pp. 1723-1729, 2011.

[147] Y.-F. Fan, R. Zhang, X. Jiang et al., “The phosphodiesterase5 inhibitor vardenafil reduces oxidative stress while reversing pulmonary arterial hypertension," Cardiovascular Research, vol. 99, no. 3, pp. 395-403, 2013.

[148] M. J. Overbeek, G. P. van Nieuw Amerongen, A. Boonstra, E. F. Smit, and A. Vonk-Noordegraaf, "Possible role of imatinib in clinical pulmonary veno-occlusive disease," European Respiratory Journal, vol. 32, no. 1, pp. 232-235, 2008.

[149] K. C. Patterson, A. Weissmann, T. Ahmadi, and H. W. Farber, "Imatinib mesylate in the treatment of refractory idiopathic pulmonary arterial hypertension," Annals of Internal Medicine, vol. 145, no. 2, pp. 152-153, 2006.

[150] R. Souza, O. Sitbon, F. Parent, G. Simonneau, and M. Humbert, "Long term imatinib treatment in pulmonary arterial hypertension," Thorax, vol. 61, article 736, 2006.

[151] H.-A. Ghofrani, N. W. Morrell, M. M. Hoeper et al., "Imatinib in pulmonary arterial hypertension patients with inadequate response to established therapy," American Journal of Respiratory and Critical Care Medicine, vol. 182, no. 9, pp. 1171-1177, 2010.

[152] M. M. Hoeper, R. J. Barst, R. C. Bourge et al., "Imatinib mesylate as add-on therapy for pulmonary arterial hypertension: results of the randomized IMPRES study," Circulation, vol. 127, no. 10, pp. 1128-1138, 2013.

[153] J. M. Edelberg, S. H. Lee, M. Kaur et al., "Platelet-derived growth factor- $\mathrm{AB}$ limits the extent of myocardial infarction in a rat model: feasibility of restoring impaired angiogenic capacity in the aging heart," Circulation, vol. 105, no. 5, pp. 608-613, 2002.

[154] P. C. H. Hsieh, C. MacGillivray, J. Gannon, F. U. Cruz, and R. T. Lee, "Local controlled intramyocardial delivery of plateletderived growth factor improves postinfarction ventricular function without pulmonary toxicity," Circulation, vol. 114, no. 7, pp. 637-644, 2006.

[155] S. Farha, R. Dweik, F. Rahaghi et al., "Imatinib in pulmonary arterial hypertension: c-Kit inhibition," Pulmonary Circulation, vol. 4, no. 3, pp. 452-455, 2014.

[156] T. E. King Jr., W. Z. Bradford, S. Castro-Bernardini et al., "A phase 3 trial of pirfenidone in patients with idiopathic pulmonary fibrosis," The New England Journal of Medicine, vol. 370, no. 22, pp. 2083-2092, 2014.

[157] L. Richeldi, R. M. du Bois, G. Raghu et al., "Efficacy and safety of nintedanib in idiopathic pulmonary fibrosis," The New England Journal of Medicine, vol. 370, no. 22, pp. 2071-2082, 2014.

[158] D. Valeyre, C. Albera, W. Z. Bradford et al., "Comprehensive assessment of the long-term safety of pirfenidone in patients with idiopathic pulmonary fibrosis," Respirology, vol. 19, no. 5, pp. 740-747, 2014.

[159] Y. Wang, Y. Wu, J. Chen, S. Zhao, and H. Li, "Pirfenidone attenuates cardiac fibrosis in a mouse model of TAC-induced left ventricular remodeling by suppressing NLRP3 Inflammasome formation," Cardiology, vol. 126, no. 1, pp. 1-11, 2013.

[160] D. T. Nguyen, C. Ding, E. Wilson, G. M. Marcus, and J. E. Olgin, "Pirfenidone mitigates left ventricular fibrosis and dysfunction after myocardial infarction and reduces arrhythmias," Heart Rhythm, vol. 7, no. 10, pp. 1438-1445, 2010.

[161] R. Ramos-Mondragón, C. A. Galindo, M. García-Castañeda et al., "Chronic potentiation of cardiac L-type $\mathrm{Ca}^{2+}$ channels by 
pirfenidone," Cardiovascular Research, vol. 96, no. 2, pp. 244254, 2012.

[162] T. Yamazaki, N. Yamashita, Y. Izumi et al., "The antifibrotic agent pirfenidone inhibits angiotensin II-induced cardiac hypertrophy in mice," Hypertension Research, vol. 35, no. 1, pp. 34-40, 2012.

[163] H. J. Bogaard, K. Abe, A. V. Noordegmaf, and N. F. Voelkel, “The right ventricle under pressure: cellular and molecular mechanisms of right-heart failure in pulmonary hypertension," Chest, vol. 135, no. 3, pp. 794-804, 2009.

[164] M. Guglin and S. Verma, "Right side of heart failure," Heart Failure Reviews, vol. 17, no. 3, pp. 511-527, 2012.

[165] M. C. van de Veerdonk, T. Kind, J. T. Marcus et al., "Progressive right ventricular dysfunction in patients with pulmonary arterial hypertension responding to therapy," Journal of the American College of Cardiology, vol. 58, no. 24, pp. 2511-2519, 2011.

[166] J. Gomez-Arroyo, J. Sandoval, M. A. Simon, E. DominguezCano, N. F. Voelkel, and H. J. Bogaard, "Treatment for pulmonary arterial hypertension-associated right ventricular dysfunction," Annals of the American Thoracic Society, vol. 11, no. 7, pp. 1101-1115, 2014.

[167] A. Ciarka, V. Doan, S. Velez-Roa, R. Naeije, and P. Van De Borne, "Prognostic significance of sympathetic nervous system activation in pulmonary arterial hypertension," The American Journal of Respiratory and Critical Care Medicine, vol. 181, no. 11, pp. 1269-1275, 2010.

[168] M. R. Bristow, W. Minobe, R. Rasmussen et al., "Beta-adrenergic neuroeffector abnormalities in the failing human heart are produced by local rather than systemic mechanisms," The Journal of Clinical Investigation, vol. 89, no. 3, pp. 803-815, 1992.

[169] S. Provencher, P. Herve, X. Jais et al., "Deleterious effects of $\beta$ blockers on exercise capacity and hemodynamics in patients with portopulmonary hypertension," Gastroenterology, vol. 130, no. 1, pp. 120-126, 2006.

[170] S. Reiken, X. H. T. Wehrens, J. A. Vest et al., “ $\beta$-blockers restore calcium release channel function and improve cardiac muscle performance in human heart failure," Circulation, vol. 107, no. 19, pp. 2459-2466, 2003.

[171] J. Tongers, B. Schwerdtfeger, G. Klein et al., "Incidence and clinical relevance of supraventricular tachyarrhythmias in pulmonary hypertension," American Heart Journal, vol. 153, no. 1, pp. 127-132, 2007.

[172] I.-M. Kim, D. G. Tilley, J. Chen et al., “ $\beta$-blockers alprenolol and carvedilol stimulate $\beta$-arrestin-mediated EGFR transactivation," Proceedings of the National Academy of Sciences of the United States of America, vol. 105, no. 38, pp. 14555-14560, 2008.

[173] J. I. Drake, H. J. Bogaard, S. Mizuno et al., "Molecular signature of a right heart failure program in chronic severe pulmonary hypertension," American Journal of Respiratory Cell and Molecular Biology, vol. 45, no. 6, pp. 1239-1247, 2011.

[174] H. J. Bogaard, R. Natarajan, S. Mizuno et al., "Adrenergic receptor blockade reverses right heart remodeling and dysfunction in pulmonary hypertensive rats," American Journal of Respiratory and Critical Care Medicine, vol. 182, no. 5, pp. 652-660, 2010.

[175] K. Okumura, H. Kato, O. Honjo et al., "Carvedilol improves biventricular fibrosis and function in experimental pulmonary hypertension," Journal of Molecular Medicine, vol. 93, no. 6, pp. 663-674, 2015.

[176] F. S. de Man, M. L. Handoko, J. J. M. van Ballegoij et al., "Bisoprolol delays progression towards right heart failure in experimental pulmonary hypertension," Circulation: Heart Failure, vol. 5, no. 1, pp. 97-105, 2012.
[177] L. Piao, Y.-H. Fang, K. S. Parikh et al., "GRK2-mediated inhibition of adrenergic and dopaminergic signaling in right ventricular hypertrophy: therapeutic implications in pulmonary hypertension," Circulation, vol. 126, no. 24, pp. 2859-2869, 2012.

[178] L. M. Casey, A. R. Pistner, S. L. Belmonte et al., "Small molecule disruption of G $\beta \gamma$ signaling inhibits the progression of heart failure," Circulation Research, vol. 107, no. 4, pp. 532-539, 2010.

[179] H. Ikram, A. H. Maslowski, M. G. Nicholls, E. A. Espiner, and F. T. Hull, "Haemodynamic and hormonal effects of captopril in primary pulmonary hypertension," British Heart Journal, vol. 48, no. 6, pp. 541-545, 1982.

[180] C. V. Leier, D. Bambach, S. Nelson et al., "Captopril in primary pulmonary hypertension,” Circulation, vol. 67, no. 1, pp. 155-161, 1983.

[181] M. U. Braun, P. Szalai, R. H. Strasser, and M. M. Borst, "Right ventricular hypertrophy and apoptosis after pulmonary artery banding: regulation of PKC isozymes," Cardiovascular Research, vol. 59, no. 3, pp. 658-667, 2003.

[182] J. Gomez-Arroyo, S. Mizuno, K. Szczepanek et al., "Metabolic gene remodeling and mitochondrial dysfunction in failing right ventricular hypertrophy secondary to pulmonary arterial hypertension," Circulation: Heart Failure, vol. 6, no. 1, pp. 136144, 2013.

[183] Y.-H. Fang, L. Piao, Z. Hong et al., “Therapeutic inhibition of fatty acid oxidation in right ventricular hypertrophy: exploiting Randle's cycle," Journal of Molecular Medicine, vol. 90, no. 1, pp. 31-43, 2012.

[184] H. Ashrafian, M. P. Frenneaux, and L. H. Opie, "Metabolic mechanisms in heart failure," Circulation, vol. 116, no. 4, pp. 434-448, 2007.

[185] H. J. Bogaard, R. Natarajan, S. C. Henderson et al., "Chronic pulmonary artery pressure elevation is insufficient to explain right heart failure," Circulation, vol. 120, no. 20, pp. 1951-1960, 2009.

[186] D. A. Mann and F. Oakley, "Serotonin paracrine signaling in tissue fibrosis," Biochimica et Biophysica Acta-Molecular Basis of Disease, vol. 1832, no. 7, pp. 905-910, 2013.

[187] K.-G. Shyu, "Serotonin $5-\mathrm{HT}_{2 \mathrm{~B}}$ receptor in cardiac fibroblast contributes to cardiac hypertrophy: a new therapeutic target for heart failure?" Circulation Research, vol. 104, no. 1, pp. 1-3, 2009.

[188] O. Lairez, T. Cognet, S. Schaak et al., "Role of serotonin 5-HT2A receptors in the development of cardiac hypertrophy in response to aortic constriction in mice," Journal of Neural Transmission, vol. 120, no. 6, pp. 927-935, 2013.

[189] W. Janssen, Y. Schymura, T. Novoyatleva et al., "5-HT2B receptor antagonists inhibit fibrosis and protect from RV heart failure," BioMed Research International, vol. 2015, Article ID 438403, 8 pages, 2015.

[190] R. Hambrecht, E. Fiehn, C. Weigl et al., "Regular physical exercise corrects endothelial dysfunction and improves exercise capacity in patients with chronic heart failure," Circulation, vol. 98, no. 24, pp. 2709-2715, 1998.

[191] D. Mereles, N. Ehlken, S. Kreuscher et al., "Exercise and respiratory training improve exercise capacity and quality of life in patients with severe chronic pulmonary hypertension," Circulation, vol. 114, no. 14, pp. 1482-1489, 2006.

[192] I. Goldenberg, V. Kutyifa, H. U. Klein et al., "Survival with cardiac-resynchronization therapy in mild heart failure," The New England Journal of Medicine, vol. 370, no. 18, pp. 1694-1701, 2014.

[193] J. T. Marcus, C. T.-J. Gan, J. J. M. Zwanenburg et al., "Interventricular mechanical asynchrony in pulmonary arterial hypertension: left-to-right delay in peak shortening is related to right 
ventricular overload and left ventricular underfilling," Journal of the American College of Cardiology, vol. 51, no. 7, pp. 750-757, 2008.

[194] M. L. Handoko, R. R. Lamberts, E. M. Redout et al., "Right ventricular pacing improves right heart function in experimental pulmonary arterial hypertension: a study in the isolated heart," American Journal of Physiology-Heart and Circulatory Physiology, vol. 297, no. 5, pp. H1752-H1759, 2009.

[195] N. Espinola-Zavaleta, J. Vargas-Barrón, J. I. Tazar et al., "Echocardiographic evaluation of patients with primary pulmonary hypertension before and after atrial septostomy," Echocardiography, vol. 16, no. 7, pp. 625-634, 1999.

[196] A. Ciarka, J.-L. Vachièry, A. Houssière et al., "Atrial septostomy decreases sympathetic overactivity in pulmonary arterial hypertension," Chest, vol. 131, no. 6, pp. 1831-1837, 2007.

[197] M. Berman, S. Tsui, A. Vuylsteke, A. Klein, and D. P. Jenkins, "Life-threatening right ventricular failure in pulmonary hypertension: RVAD or ECMO?" Journal of Heart and Lung Transplantation, vol. 27, no. 10, pp. 1188-1189, 2008.

[198] M. Berman, S. Tsui, A. Vuylsteke et al., "Successful extracorporeal membrane oxygenation support after pulmonary thromboendarterectomy," Annals of Thoracic Surgery, vol. 86, no. 4, pp. 1261-1267, 2008.

[199] K. Furukawa, T. Motomura, and Y. Nosé, "Right ventricular failure after left ventricular assist device implantation: the need for an implantable right ventricular assist device," Artificial Organs, vol. 29, no. 5, pp. 369-377, 2005.

[200] J. K. Bhama, R. L. Kormos, Y. Toyoda, J. J. Teuteberg, K. R. McCurry, and M. P. Siegenthaler, "Clinical experience using the Levitronix CentriMag system for temporary right ventricular mechanical circulatory support," Journal of Heart and Lung Transplantation, vol. 28, no. 9, pp. 971-976, 2009.

[201] G. M. Giesler, J. S. Gomez, G. Letsou, M. Vooletich, and R. W. Smalling, "Initial report of percutaneous right ventricular assist for right ventricular shock secondary to right ventricular infarction," Catheterization and Cardiovascular Interventions, vol. 68, no. 2, pp. 263-266, 2006.

[202] A. W. Cheung, C. W. White, M. K. Davis, and D. H. Freed, "Short-term mechanical circulatory support for recovery from acute right ventricular failure: clinical outcomes," The Journal of Heart and Lung Transplantation, vol. 33, no. 8, pp. 794-799, 2014.

[203] J. A. Goldstein and M. J. Kern, "Percutaneous mechanical support for the failing right heart," Cardiology Clinics, vol. 30, no. 2, pp. 303-310, 2012.

[204] J. M. Schaffer, S. K. Singh, B. A. Reitz, R. T. Zamanian, and H. R. Mallidi, "Single- vs double-lung transplantation in patients with chronic obstructive pulmonary disease and idiopathic pulmonary fibrosis since the implementation of lung allocation based on medical need," The Journal of the American Medical Association, vol. 313, no. 9, pp. 936-948, 2015.

[205] L. U. Nwakanma, C. E. Simpkins, J. A. Williams et al., "Impact of bilateral versus single lung transplantation on survival in recipients 60 years of age and older: analysis of United Network for Organ Sharing database," Journal of Thoracic and Cardiovascular Surgery, vol. 133, no. 2, pp. 541-547, 2007.

[206] S. Lehmann, M. Uhlemann, S. Leontyev et al., "Bilateral versus single lung transplant for idiopathic pulmonary fibrosis," Experimental and Clinical Transplantation, vol. 12, pp. 443-447, 2014. 


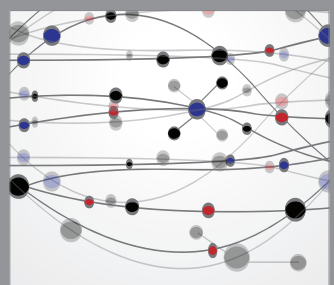

The Scientific World Journal
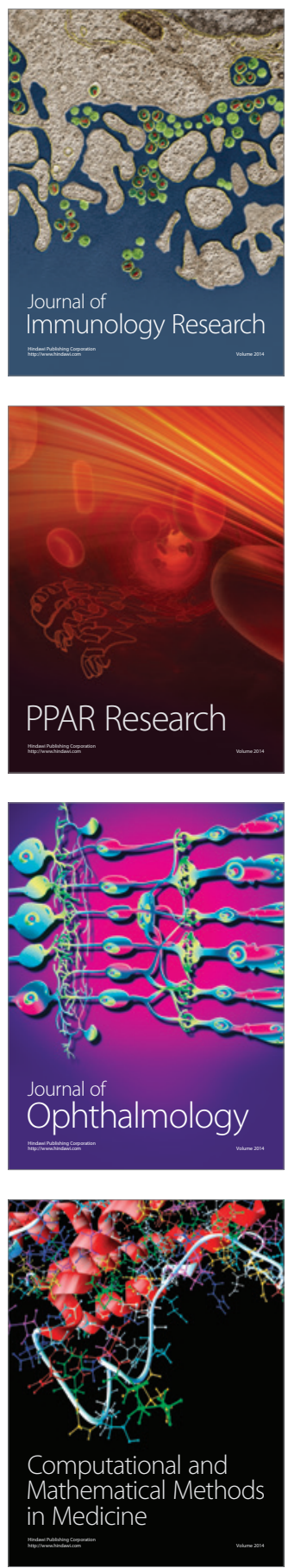

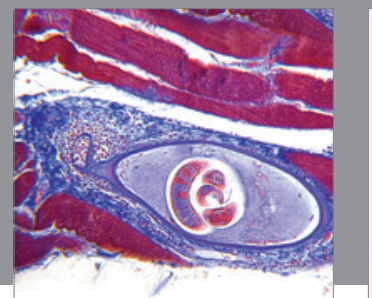

Gastroenterology

Research and Practice
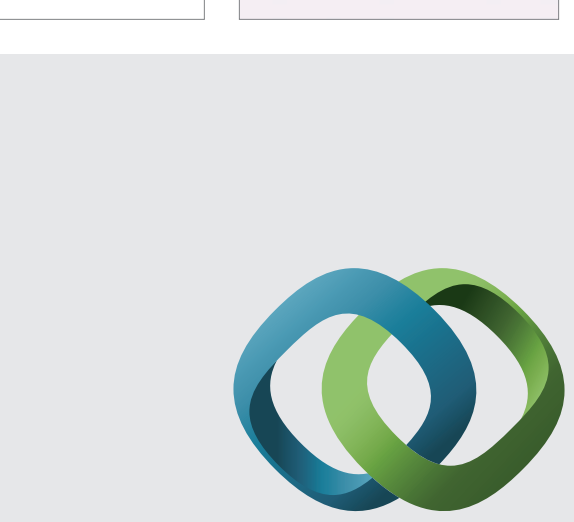

\section{Hindawi}

Submit your manuscripts at

http://www.hindawi.com
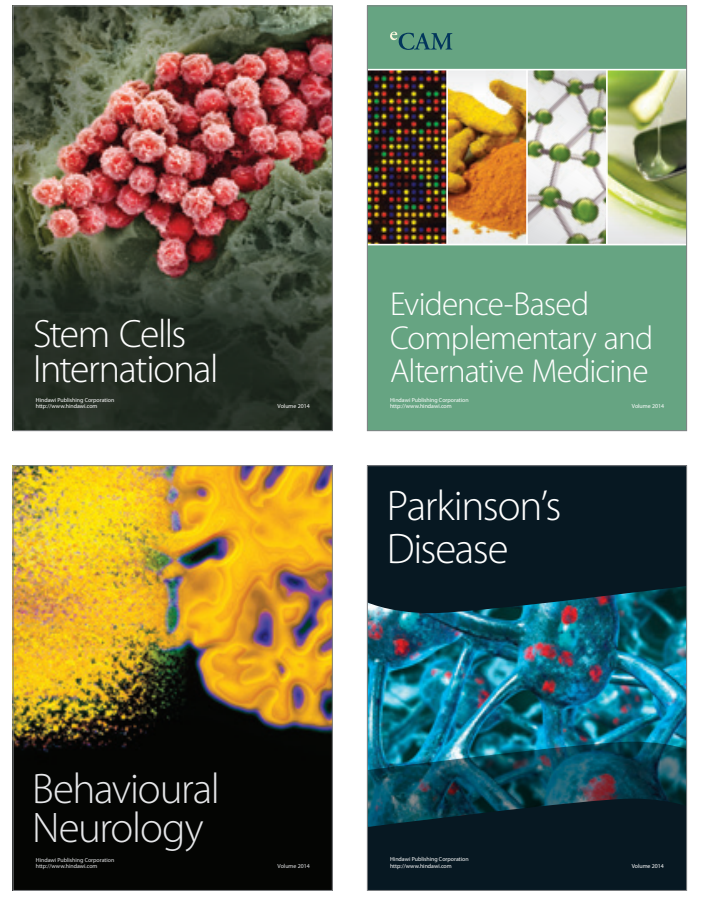
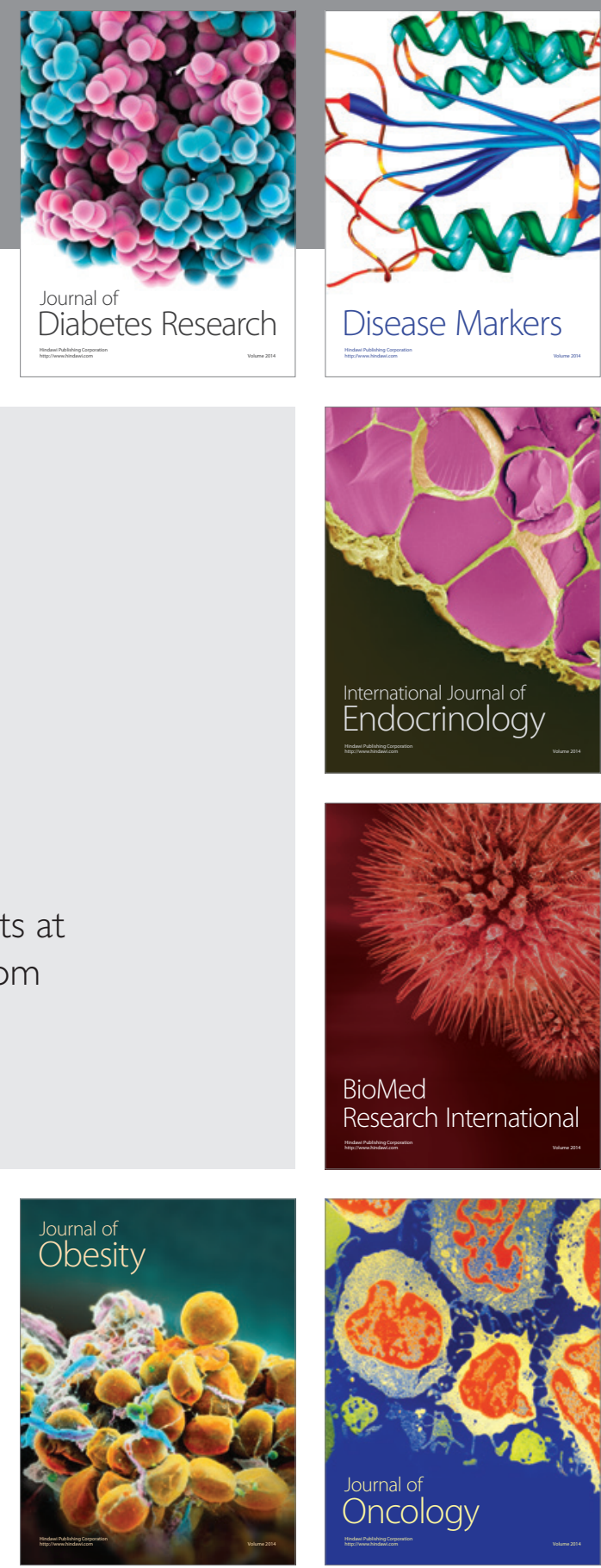

Disease Markers
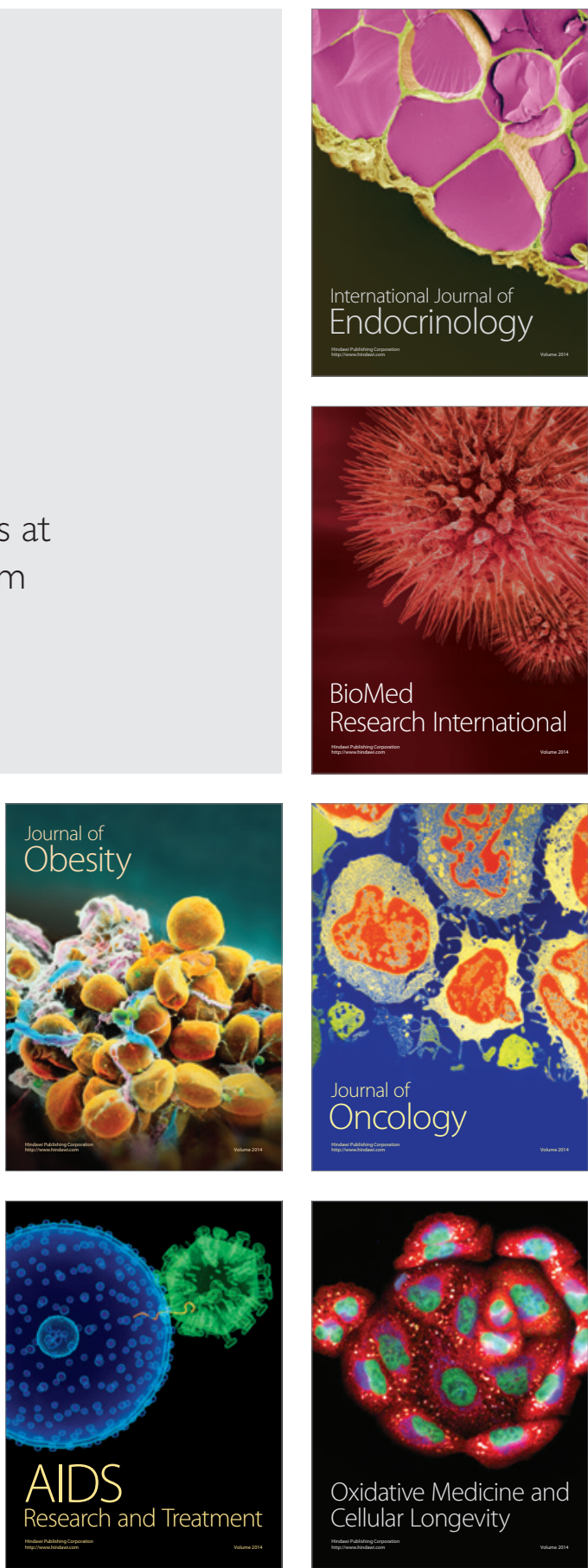